\title{
Postinjury Induction of Activated ErbB2 Selectively Hyperactivates Denervated Schwann Cells and Promotes Robust Dorsal Root Axon Regeneration
}

\author{
는 Seung Baek Han, Hyukmin Kim, Hyunkyoung Lee, Matthew Grove, George M. Smith, and Young-Jin Son \\ Shriners Hospitals Pediatric Research Center and Center for Neural Repair and Rehabilitation, Department of Anatomy and Cell Biology, Lewis Katz School \\ of Medicine, Temple University, Philadelphia, Pennsylvania 19140
}

Following nerve injury, denervated Schwann cells (SCs) convert to repair SCs, which enable regeneration of peripheral axons. However, the repair capacity of SCs and the regenerative capacity of peripheral axons are limited. In the present studies we examined a potential therapeutic strategy to enhance the repair capacity of SCs, and tested its efficacy in enhancing regeneration of dorsal root (DR) axons, whose regenerative capacity is particularly weak. We used male and female mice of a doxycycline-inducible transgenic line to induce expression of constitutively active ErbB2 (caErbB2) selectively in SCs after DR crush or transection. Two weeks after injury, injured DRs of induced animals contained far more SCs and SC processes. These SCs had not redifferentiated and continued to proliferate. Injured DRs of induced animals also contained far more axons that regrew along SC processes past the transection or crush site. Remarkably, SCs and axons in uninjured DRs remained quiescent, indicating that caErbB2 enhanced regeneration of injured DRs, without aberrantly activating SCs and axons in intact nerves. We also found that intraspinally expressed glial cell line-derived neurotrophic factor (GDNF), but not the removal of chondroitin sulfate proteoglycans, greatly enhanced the intraspinal migration of caErbB2-expressing SCs, enabling robust penetration of DR axons into the spinal cord. These findings indicate that SC-selective, post-injury activation of ErbB2 provides a novel strategy to powerfully enhance the repair capacity of SCs and axon regeneration, without substantial off-target damage. They also highlight that promoting directed migration of caErbB2-expressing SCs by GDNF might be useful to enable axon regrowth in a non-permissive environment.

Key words: dorsal root regeneration; ErbB2; GDNF; neuregulin; peripheral nerve regeneration; Schwann cell

Significance Statement

Repair of injured peripheral nerves remains a critical clinical problem. We currently lack a therapy that potently enhances axon regeneration in patients with traumatic nerve injury. It is extremely challenging to substantially increase the regenerative capacity of damaged nerves without deleterious off-target effects. It was therefore of great interest to discover that caErbB2 markedly enhances regeneration of damaged dorsal roots, while evoking little change in intact roots. To our knowledge, these findings are the first demonstration that repair capacity of denervated SCs can be efficaciously enhanced without altering innervated SCs. Our study also demonstrates that oncogenic ErbB2 signaling can be activated in SCs but not impede transdifferentiation of denervated SCs to regeneration-promoting repair SCs.

\section{Introduction}

The regenerative capacity of the PNS greatly exceeds that of the CNS largely due to Schwann cells (SCs) that potently support

Received March 29, 2017; revised Sept. 20, 2017; accepted Sept. 27, 2017.

Author contributions: Y.-J.S. designed research; S.B.H., H.K., and H.L. performed research; G.M.S. contributed unpublished reagents/analytic tools; S.B.H., H.K., H.L., M.G., G.M.S., and Y.-J.S. analyzed data; S.B.H. and Y.-J.S. wrote the paper.

This work was supported by Shriners Hospitals for Children and NIH NINDS (NS079631 and NS095070 to Y.-J.S.) and Neural Repair Viral Core (G.M.S.). We thank Alan Tessler and members of the Son laboratory for critical reading of the paper; Dr. Wes Thompson for S100-rtTA;tet0-Neu-NT line; Dr. Stephen Strittmatter for SPRR1A antibody; and Drs. Christopher Hayworth, Shuxin Li, Mary Barbe, Gareth Thomas, and Seonhee Kim for sharing resources and technical help. axon regeneration (Zochodne, 2012; Scheib and Höke, 2013; Jessen and Mirsky, 2016). Nonetheless, peripheral axons regenerate slowly and rarely over long distances, which limits the functional recovery of patients with proximal or chronic nerve injuries (Höke, 2006; Sulaiman and Gordon, 2009; Gordon, 2016). Experimental strategies have largely attempted to enhance regener-

Correspondence should be addressed to Dr. Young-Jin Son, Temple University School of Medicine, MERB, 6th Floor, 3500 North Broad Street, Philadelphia, PA 19140. E-mail: yson@temple.edu.

D0I:10.1523/JNEUROSCI.0903-17.2017

Copyright $\odot 2017$ the authors $\quad 0270-6474 / 17 / 3710955-16 \$ 15.00 / 0$ 
ation by targeting neurons (Scholz et al., 2009; Chan et al., 2014; Kuffler, 2014; Gordon and English, 2016; Palispis and Gupta, 2017). Their clinical applications are, however, hampered by inconsistent efficacy and/or undesirable off-target effects. Increasing evidence suggests that impaired regeneration is primarily due to denervated SCs that become less supportive over time and with aging (Fu and Gordon, 1995; Sulaiman and Gordon, 2000; Gordon et al., 2011; Kang and Lichtman, 2013; Painter et al., 2014). An alternative strategy therefore would be to enhance the repair capacity of denervated SCs without inflicting off-target damage.

Following nerve injury, denervated SCs rapidly dedifferentiate, proliferate, and convert to regeneration-promoting SCs, termed repair SCs (Jessen and Mirsky, 2016). Several signaling mediators upregulated in the denervated SC have been implicated in this conversion, including ErbB2 receptor tyrosine kinase (Sheu et al., 2000; Harrisingh et al., 2004; Guertin et al., 2005; Arthur-Farraj et al., 2012; Napoli et al., 2012; Yang et al., 2012). The ErbB2 in SC forms signaling complexes with ErbB3 and becomes activated when ErbB3 binds to Neuregulin-1 (Gambarotta et al., 2013; Kidd et al., 2013). Activated ErbB2 signals through several downstream effectors, including Erk and Akt, which are potent stimulators of SC proliferation (Maurel and Salzer, 2000; Monje et al., 2006; Mårtensson et al., 2007; Shin et al., 2013). Conditional induction of mutant, constitutively active ErbB2 (caErbB2) selectively in SCs of intact adult animals (i.e., "innervated" SCs), has consistently induced SC proliferation and process extension (Hayworth et al., 2006). It also induces axon sprouting and newly formed axons extending along SC processes, suggesting that quiescent SCs are converted to growth-promoting SCs. Notably, ErbB2 is only transiently upregulated in "denervated" SCs after injury and SC proliferation progressively declines (Carroll et al., 1997; Guertin et al., 2005; Triolo et al., 2006; Lino et al., 2007). These data prompted us to hypothesize that elevating ErbB2 activation will enhance repair capacity of denervated SCs and thus enhance axon regeneration.

Because peripheral nerves regenerate well in rodents, in which a relatively short distance of axon regrowth is required, it can be difficult to evaluate the efficacy and vigor of an experimental treatment. The central axon branches of dorsal root ganglion (DRG) neurons regenerate substantially more slowly than peripheral branches (Wujek and Lasek, 1983; Oblinger and Lasek, 1984; Chong et al., 1994; Di Maio et al., 2011). Dorsal root (DR) axons frequently fail to regenerate across a transection injury, an additional indication that their regenerative capacity is significantly weaker than that of peripheral nerve (Di Maio et al., 2011). Moreover, DR axons that grow slowly along the root completely stop regenerating at the entrance to the spinal cord, the DR entry zone (DREZ; Ramer et al., 2001; Havton and Carlstedt, 2009; Smith et al., 2012). Few treatments have enabled robust penetration of diverse subtypes of DR axons across the DREZ. The rodent DR injury model therefore allows treatments to be tested under particularly challenging conditions for axon regrowth.

We report the first demonstration that ErbB2 signaling can be activated to dramatically enhance the repair capacity of SCs in damaged nerves, without evoking aberrant changes in intact nerves. We also show that caErbB2 induction can be even more powerful in combination with glial cell line-derived neurotrophic factor (GDNF); combining both strategies produces unprecedentedly robust penetration of DR axons into the spinal cord. These findings have important implications for the regulation of SC plasticity after injury and potentially for the development of novel treatments for nerve repair.

\section{Materials and Methods}

Mice. S100-rtTA;tetO-caErbB2(Neu-NT) mice were described previously (Hayworth et al., 2006). To facilitate observation of regenerating axons, S100-rtTA;tetO-caErbB2 mice were bred with thy1-YFPH mice (Feng et al., 2000). S100-rtTA;tetO-caErbB2 and S100-rtTA;tetO-caErbB2; thyl-YFPH mice were maintained in heterozygous condition for the caErbB2 transgene by breeding with C57BL/6J obtained from The Jackson Laboratory. All experiments were performed in accordance with the Temple University Institutional Animal Care and Use Committee and National Institutes of Health guidelines.

Doxycycline administration. For induction of adult animals, $120 \mathrm{mg}$ of doxycycline-HCl (Dox; D9891, Sigma-Aldrich) and $1 \mathrm{~g}$ of sucrose were first dissolved in $12 \mathrm{ml}$ of water and then mixed with $20 \mathrm{~g}$ of pulverized rodent chow. Mice were fed ad libitum; Dox food was made fresh every other day for 2 weeks. To monitor food consumption, mice were caged individually during the experiment.

DR injury. For crush or transection injury, we used S100-rtTA;tetOcaErbB2 or S100-rtTA;tetO-caErbB2;thy1-YFPH of either sex, which were heterozygous for caErbB2 allele and 2-4 months old. These mice were anesthetized with an intraperitoneal injection of xylazine $(8 \mathrm{mg} / \mathrm{kg})$ and ketamine $(120 \mathrm{mg} / \mathrm{kg})$. Supplements were given during the procedure as needed. A 2- to 3-cm-long incision was made in the skin of the back, the spinal musculature was reflected and the C5-C8 or L3-S1 spinal cord segments were exposed by hemilaminectomies for unilateral C5-C8 root crush or L4-L5 root transection surgery, respectively. The cavity made by the laminectomies was perfused with warm sterile Ringer's solution. For crush injury, a small incision was made in the dura overlying each targeted DR (C5-C8), a fine forceps (Dumont \#5; Fine Science Tools) was introduced subdurally and the DR was crushed for $10 \mathrm{~s}$. For transection injury, the L4 and L5 DRs were completely cut and a $\sim 0.5 \mathrm{~cm}$ segment removed with a microscissors. The proximal and distal stumps were then closely apposed and aligned. To avoid scar formation and possible compression, we applied a piece of thin SILASTIC membrane (Biobrane, Bertek Pharmaceuticals) over the laminectomy site and covered it with a layer of much thicker artificial dura (Gore Preclude MVP Dura Substitute, W.L. Gore and Associates). The overlying musculature was closed with 5-0 sutures, and the skin was closed with wound clips. All animals received subcutaneous injections of saline $(0.9 \% \mathrm{w} / \mathrm{v} \mathrm{NaCl})$ and buprenorphine $(0.05 \mathrm{mg} / \mathrm{kg})$ for postoperative pain management and remained on a heating pad until fully recovered from anesthesia. Mice were perfused 2 weeks after the crush, and axon regeneration through the DRs was analyzed in cryostat sections or in a thin dorsal slice preparation of whole spinal cord.

Luciferase assay. Luciferase activity was analyzed using the Luciferase Assay System following the instructions of the manufacturer (E4020; Promega). Snap-frozen tissues were homogenized in 500 or $1000 \mu \mathrm{l} 1 \times$ reporter lysis buffer. Tissue lysates were centrifuged at 13,200 rpm for 5 min at $4^{\circ} \mathrm{C}$, and supernatants were collected in new tubes. Twenty microliters of supernatant were mixed with luciferase assay substrate, and luciferase activity was measured. Luciferase activity levels were normalized to total protein as determined using the Bradford method per the instructions of the manufacturer (Bio-Rad).

Western blot analysis. Tissues (spinal cord, sciatic nerve, intact DR, or crushed DR) were snap-frozen in liquid nitrogen, thawed in chilled $0.1 \mathrm{M}$ PBS, homogenized by sonication, and centrifuged at $13,200 \mathrm{rpm}$ for $10 \mathrm{~min}$ at $4^{\circ} \mathrm{C}$. Concentration of each supernatant was determined by Bradford protein assay at A595. Thirty micrograms of each sample was mixed with $2 \times$ SDS sample buffer $(0.12 \mathrm{M}$ Tris, pH 6.8, 4\% SDS, $20 \%$ glycerol, $10 \% \beta$-mercaptoethanol, and $0.5 \%$ bromophenol blue), boiled and loaded to $12 \%$ SDS-PAGE, and then electrotransferred onto the nitrocellulose membrane (GE Healthcare) at $320 \mathrm{~mA}$ for $1 \mathrm{~h}$. After protein transfer, the membrane was washed with TBST and incubated in 5\% skim milk in TBST for 30 min. Blocked membrane was incubated primarily with rabbit anti-firefly luciferase (Abcam, ab21176; 1:400, RRID: AB_446076), rabbit anti- $\beta$-tubulin (Abcam, ab18207; 1:1000, RRID: AB_444319), and mouse anti- $\beta$-actin (Sigma-Aldrich, A5441; $1: 1000$, RRID:AB_476744) as a loading control for $1 \mathrm{~h}$, followed by incubation with HRP-conjugated goat anti-rabbit antibody (Santa Cruz Biotech- 
nology, SC2030; 1:10,000, RRID:AB_631747) or HRP-conjugated goat anti-mouse antibody (Jackson ImmunoResearch, 115-035-174; 1:10,000, RRID:AB_2338512) for 30 min after washing three times with TBST. Membrane was exposed to enhanced chemiluminescence (ECL) film (Genemate) and detected with Western blot ECL reagents (Santa Cruz Biotechnology).

Microinjection of viral vectors. Recombinant self complementary adeno-associated virus 2 (scAAV2) carrying GFP was generated by helper virus-free system (Ayuso et al., 2010) as described previously (Liu et al., 2016). Replication deficient lentiviruses encoding either chABC (LVchABC) or GDNF (LV-GDNF) used a pBOB lentiviral expression vector with $\mathrm{CMV}$-enhanced chicken $\beta$-actin (CAG) promoter. The procedures to generate the viruses and their efficacy were described previously; LVchABC (Curinga et al., 2007; Jin et al., 2011) and LV-GDNF (L. Zhang et al., 2009; Deng et al., 2013; C. Zhang et al., 2013; Kelamangalath et al., 2015). AAV2-GFP was microinjected into cervical or lumbar DRGs using a micropipette pulled to a diameter of $0.05 \mathrm{~mm}$ and a nanoinjector (World Precision Instruments). The viruses were injected at the time of DR crush or transection. For each injection, micropipette was introduced $0.5 \mathrm{~mm}$ into the DRGs and a total volume of lentivirus $(0.8 \mu \mathrm{l})$ containing $1 \times 10^{7}$ transducing units/ $\mu$ l was injected over a $10 \mathrm{~min}$ injection period. The glass needle was left in place for $2 \mathrm{~min}$ after each injection. For LV-GDNF, five injections of $0.3 \mu$ l lentivirus (a total of $2 \times$ $10^{7}$ viral particles) were equally spaced rostrocaudally along the C5-C8 DREZ. Injections were made at a rate of $100 \mathrm{nl} / \mathrm{min}$ at a depth of $0.25 \mathrm{~mm}$ from the spinal cord dorsal surface.

Immunohistochemistry. Animals were transcardially perfused with $1 \times$ PBS, $\mathrm{pH} 7.4$, followed by $4 \%$ paraformaldehyde in PBS, $\mathrm{pH} 7.4$. The spinal cords containing DRs were dissected out and stored in 30\% sucrose in $\mathrm{PBS}, \mathrm{pH} 7.4$, overnight at $4^{\circ} \mathrm{C}$ for cryoprotection. Tissues were frozen-embedded in cryoprotectant medium (ThermoFisher Scientific) in isomethylbutane at $-80^{\circ} \mathrm{C}$. Twenty micrometer cross-sections from the spinal cords were cut using a cryostat (Leica Microsystems) and collected directly onto slide glasses. For immunolabeling, sections were rinsed in three changes, $10 \mathrm{~min}$ each, of $1 \times$ PBS, incubated in $0.1 \mathrm{M}$ glycine in $1 \times$ PBS for $15 \mathrm{~min}$, and blocked in $0.2 \%$ Triton X-100, 2\% bovine serum albumin (BSA) in $1 \times$ PBS for $15 \mathrm{~min}$. Sections were incubated with primary antibodies overnight at $4^{\circ} \mathrm{C}$, washed with $2 \% \mathrm{BSA}$ in PBS three times 10 min each, and incubated with secondary antibodies for $1 \mathrm{~h}$. Primary antibodies were used at the following concentrations for immunohistochemistry: mouse anti-c-Jun (BD Biosciences, 610326; 1:500, RRID:AB_397716), rabbit anti-firefly luciferase (Abcam, ab21176; 1:400, RRID:AB_446076), rabbit anti- $\beta$-Tubulin (Abcam, ab18207; 1:1000, RRID:AB_444319), mouse anti-SC2E (Cosmo Bio, CAC-GU01-M01AS-A; 1:10,000, RRID:AB_1962608), rabbit anti-GFAP (Dako Cytomation, N1506; 1:500, RRID:AB_10013482), mouse anti-GFAP (Sigma-Aldirch, G3893; 1:500, RRID:AB_477010), rabbit anti-Ki67 (Millipore, ab9260; 1:500, RRID:AB_2142366), mouse anti-SMI312 (Sternberger, SMI312; 1:1000, RRID:AB_2314902), rabbit anti-NF200 (Sigma-Aldrich, N4142; 1:500, RRID:AB_477272), rabbit anti-CGRP (Peninsula Histopathology Laboratory, T-4032; 1:2000, RRID:AB_2307330), goat anti-p75NGFR (Neuromics, GT15057; 1:500, RRID:AB_1611758), mouse anti-CS56 (Sigma-Aldrich, C8035; 1:400, RRID: AB_476879), mouse anti-NCAM (DSHB, AG1; 1:10, RRID:AB_528394), goat anti-Ret (R\&D Systems, BAF482; 1:100, RRID:AB_2179763), guinea pig anti-Sox10 (Dr. Michael Wegner, University of Erlangen, Germany; 1:1000), and rabbit anti-SPRR1A (Abcam, ab125374; 1:10, RRID: AB_11130171). All antibodies were diluted in 2\% BSA in PBS. Sections were washed in three changes of PBS, 10 min each, and mounted with Vectashield mounting medium (Vector Laboratories; RRID:AB_2336789). Images were acquired using a SP8 confocal microscope (Leica Microsystems), or an epifluorescence M2 microscope (Zeiss), Orca-R2 CCD controller and camera (Hamamatsu), and Imaris software (Bitplane).

Analysis of regeneration across the DREZ. The location of the DREZ, the CNS/PNS interface, is demarcated by GFAP immunostaining of astrocytes. The yellow curved lines in Figures 6, 7, and 8 approximate the location and pattern of the outer (peripheral) border of the DREZ, as defined by GFAP immunolabeling of astrocytic processes that extend peripherally. When the interface demarcated by GFAP labeling has moved, we approximate the original location of the DREZ, based on the usual distance of the DREZ from the exit point of the root from the cord or from the dorsolateral corner of the dorsal horn (e.g., $\sim 300 \mu \mathrm{m}$ at C6). We consider that axons and SCs have penetrated into the CNS when they pass the exit point of a DR from the cord (i.e., invading the dorsolateral funiculus) or when they are deeper in the dorsal horn (see Fig. 8); both locations are normally within CNS territory.

Statistical analysis. All statistical analyses were performed using PRISM 6.0 (Graphpad; RRID:SCR_002798). Statistical analysis was done using unpaired Student's $t$ test or one-way or two-way ANOVA with either Sidak's or Tukey's multiple-comparison tests. All data are presented as mean \pm SEM. Sample sizes are as described in the figure legends. Results were considered statistically significant if $p<0.05$.

\section{Results}

\section{Post-injury induction of caErbB2 in SCs}

To study the effects on DR regeneration of enhancing ErbB2 activation in SCs, we used a Tet-On based, inducible transgenic mouse line to express a mutant, constitutively active ErbB2 selectively in SCs (designated hereafter as caErbB2 cTg). The activated ErbB2 receptor tyrosine kinase (caErbB2, also known as NeuNT) is rendered constitutively active by a point mutation in its transmembrane domain (Bargmann et al., 1986). The caErbB2 cTg line was generated by mating a line expressing the reverse-tetracycline transactivator under the control of the S100 promoter (Hayworth et al., 2006), with another line that carries a Dox-dependent allele of caErbB2 (Moody et al., 2002; Fig. 1A). We further crossed the double transgenic caErbB2 cTg (i.e., S100-rtTA;tetO-NeuNT) with a fluorescent line in which subsets of neurons express YFP [i.e., Thy1YFPH (Feng et al., 2000), hereafter as caErbB2-YFPH cTg].

An earlier study, which extensively assessed the inducibility and specificity of the transgene expression in the caErbB2 cTg, showed Dox-dependent, rapid, reversible, and SC-selective induction of caErbB2 expression (Hayworth et al., 2006). This study analyzed innervated SCs in muscles and sciatic nerves of uninjured caErbB2 cTg mice (Hayworth et al., 2006). We first sought to confirm the transgene induction in intact and damaged DRs of caErbB2 cTg mice and assessed expression of the luciferase reporter driven by the IRES in the caErbB2 transgene (Moody et al., 2002; Hayworth et al., 2006). We crushed cervical DRs of young adult mice and fed them Dox-containing food from the day of the surgery. Two weeks after the root crush, we harvested ipsilateral (crushed) and contralateral (intact) DRs of Dox-fed or unfed caErbB2 cTg and carried out a luciferase assay (Fig. $1 B$ ) and Western blotting (Fig. 1C). As expected, we did not detect luciferase expression (or by inference, caErbB2 expression) in DRs of Dox-fed Thy1-YFPH control animals or of Doxunfed, uninduced caErbB2 cTg mice (Fig. $1 B, C$ ). In contrast, luciferase activity increased $\sim 10,000,000$-fold over baseline in the ipsilateral (injured) DRs of induced caErbB2 cTg animals distal to nerve crush (Fig. 1B). Luciferase activity also increased in contralateral (intact) DRs of the same induced animals but at a much lower level ( $\sim 2,000,000$-fold over baseline; $\sim 5$-fold less than in injured DRs). Western blotting also revealed a higher level of transgene induction in crushed than in intact DRs (Fig. 1C).

Immunohistochemical analysis revealed luciferase-positive cells only in induced animals, and staining by a SC-specific Sox10 antibody confirmed that the cells were SCs in intact (Fig. 1D) and injured roots (Fig. 1E). Due to the low sensitivity of the available luciferase antibodies, we were unable to reliably quantify SCs that express caErbB2 (i.e., luciferase-positive SCs) and compare intact to injured roots. In summary, these results confirm the inducibility and SC specificity of caErbB2 expression in intact and injured DRs of caErbB2 cTg mice. 
A

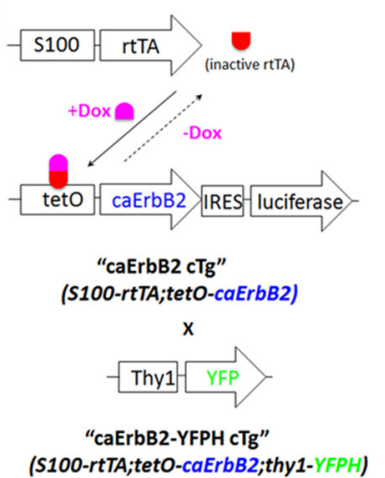

B

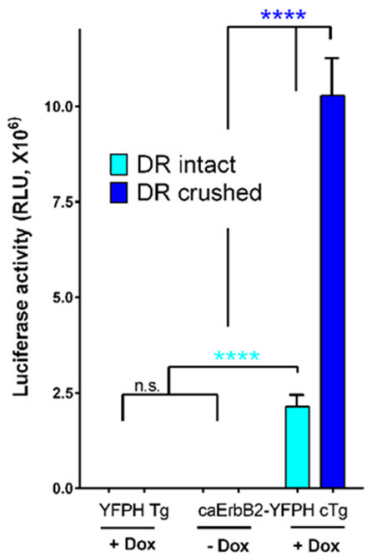

C
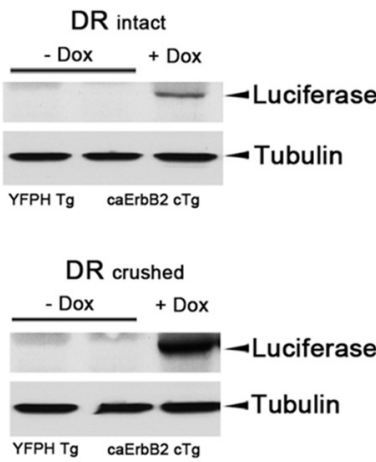
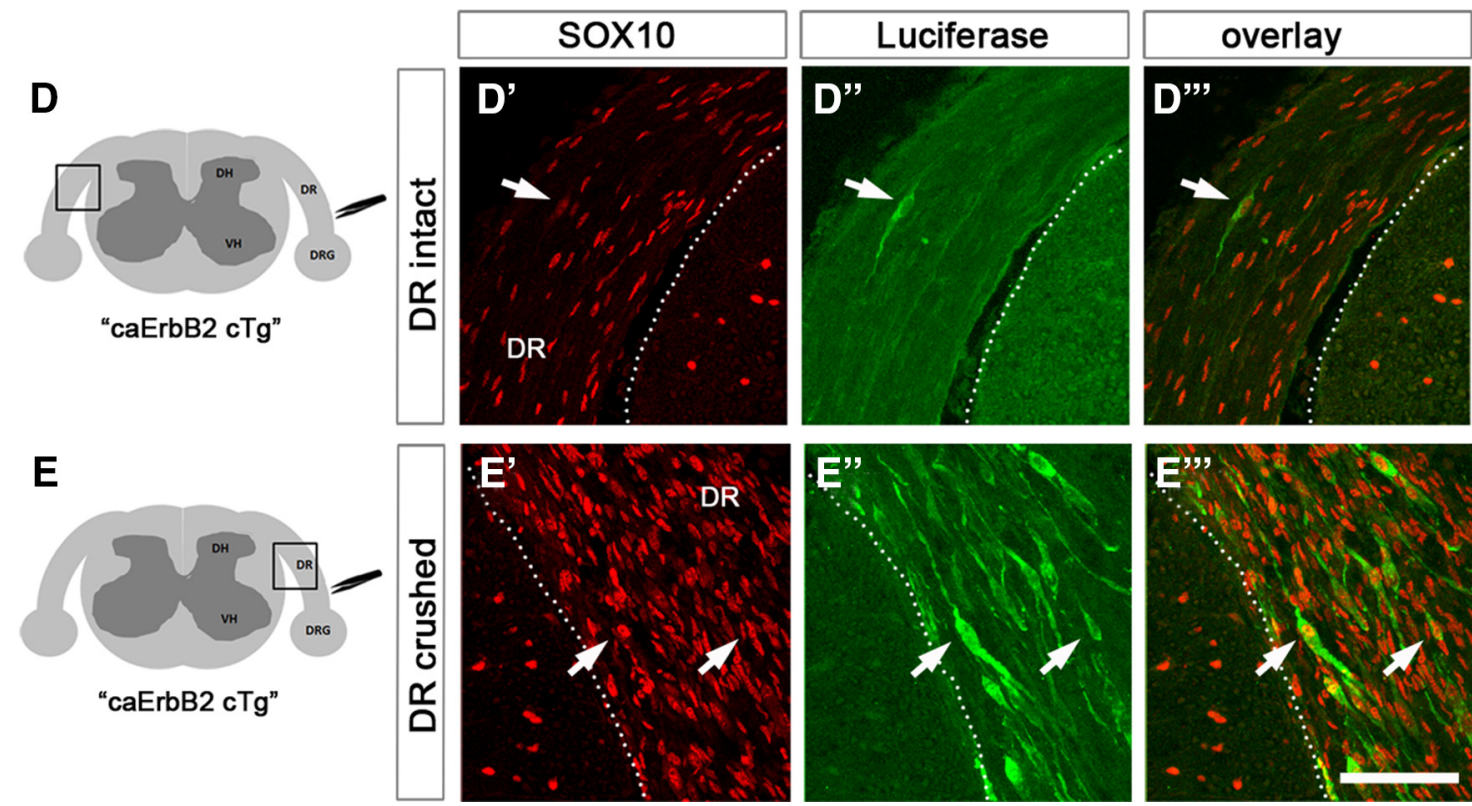

Figure 1. Post-injury induction of caErbB2 in SCS. A, A schematic diagram showing generation of caErbB2 cTg mouse, a double-transgenic line based on a Tet-0n system. Crossing caErbB2 cTg line with Thy1-YFPH line generated the caErbB2-YFPH triple cTg line. $\boldsymbol{B}$, Luciferase assay comparing activity of the luciferase reporter expressed from IRES in a transgene coding for caErbB2. No activity is detected in DRs of Dox-fed YFPH Tg or Dox-unfed caErbB2 cTg animals. Luciferase activity increases $\sim 2,000,000$-fold over baseline in contralateral uninjured roots (DR intact) and $\sim 10,000,000$ fold in the injured roots (DR crushed) of Dox-fed caErbB2 cTg mice. ${ }^{* * *} p<0.0001 ; \mathrm{df}=12$, n.s. $=$ not significant ( $p>0.9999$; $\mathrm{df}=12$ ); one-way ANOVA with Tukey's multiple comparison test, $n=3$ roots. C, Western blot analysis of luciferase expression confirming transgene expression in Dox-fed caErbB2 cTg animals. Greater luciferase expression in crushed than intact roots indicates a higher level of caErbB2 expression. $\mathbf{D}-\mathbf{D}^{\prime \prime}$, Immunohistochemical analysis of contralateral intact roots in an induced animal, showing that a cell (arrow) strongly immunopositive for luciferase ( $\boldsymbol{D}^{\prime \prime}$ ) is a SC, as identified by Sox10, a SC-specific marker $\left(\boldsymbol{D}^{\prime}\right)$. $\boldsymbol{E}-\boldsymbol{E}^{\prime \prime \prime}$, Immunohistochemical analysis of injured DRs distal to nerve crush, showing that multiple cells (arrows) strongly immunopositive for luciferase $\left(\boldsymbol{E}^{\prime \prime}\right)$ are Sox10 SCs $\left(\boldsymbol{E}^{\prime}\right)$.

Post-injury induction of caErbB2 hyperactivates denervated, but not innervated, SCs

Neuregulin/ErbB receptor signaling is complex and context dependent (Syed et al., 2010; Fricker and Bennett, 2011; Gambarotta et al., 2013). The effects of enhancing ErbB2 activation on innervated and denervated SCs may therefore differ. To examine this possibility, we performed unilateral C5-C8 DR crush in caErbB2 cTg mice, fed them Dox-containing or normal chow, and analyzed tissues at 2 weeks after injury. In this injury model, most DR axons regenerate through the crush site, extend along the root, and arrive at the DREZ where their regeneration stops. This process takes $<1$ week (Di Maio et al., 2011), and at 2 weeks after crush SCs have begun to redifferentiate and myelinate regenerated DR axons distal to the crush site (Fig. 2I).

At 2 weeks after injury, crushed roots of induced animals were strikingly enlarged and contained many more SCs than crushed roots of uninduced animals (Fig. 2A,C). Counts of SCs, labeled by a SC-specific Sox10 antibody, revealed a $\sim 2$-fold increase in induced animals (Fig. 2D). As expected, crushed roots of uninduced animals contained only a few SCs that continued to proliferate at 2 weeks post-injury (Fig. 2E). In contrast, crushed roots of induced animals contained many more proliferating SCs (Fig. $2 G)$. Counts of proliferating SCs, labeled by a Ki67 antibody, showed a $\sim 5$-fold increase in proliferating SCs in induced animals (Fig. $2 \mathrm{H}$ ). These results show that post-injury induction of caErbB2 prolonged proliferation of denervated SCs and greatly increased the number of SCs in injured DRs.

In marked contrast, the number of SCs in contralateral intact roots of induced animals remained unaltered (Fig. 2B,D). We observed occasional Ki67+ proliferating SCs (Fig. $2 F$, arrow) but SC proliferation was insignificant in intact roots (Fig. $2 \mathrm{H}$ ). In addition, immunostaining for a SC-specific myelin marker, SC2E, showed no obvious signs of demyelination or SC dedifferentiation in intact roots of induced animals (Fig. $2 J, L$ ). The 

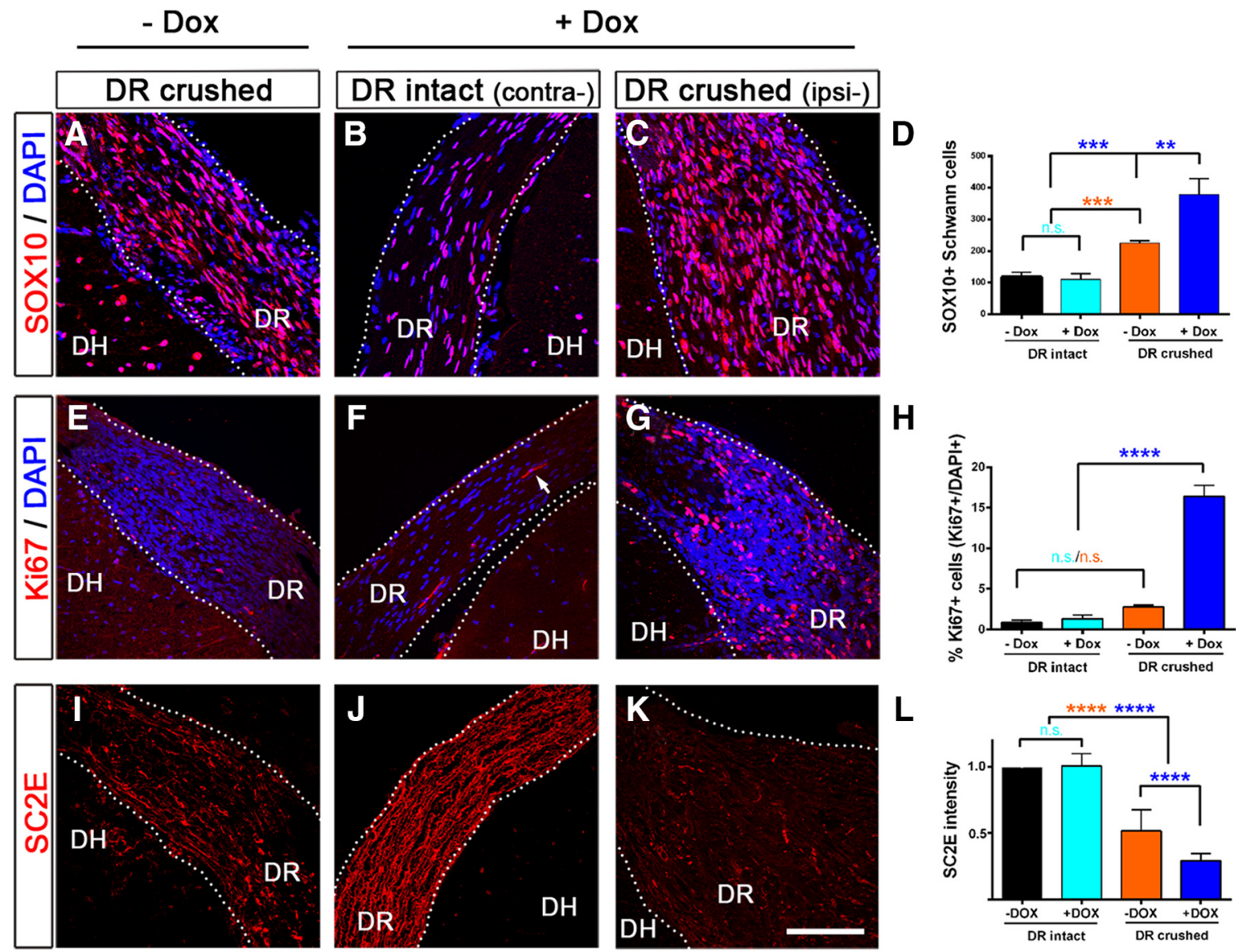

Figure 2. Selective hyperactivation of denervated SCS. Immunohistochemical comparisons between SCs in intact (data not shown) and crushed roots $(\boldsymbol{A}, \boldsymbol{E}, \boldsymbol{I})$ of uninduced animals, and SCs in intact $(\boldsymbol{B}, \boldsymbol{F}, \boldsymbol{J})$ and crushed $(\boldsymbol{C}, \boldsymbol{G}, \boldsymbol{K})$ roots of induced animals, 2 weeks after root crush. $\boldsymbol{A}-\boldsymbol{D}$, Comparisons of SC numbers. SCs are identified by Sox 10 antibody. $\boldsymbol{A}$, Injury increases $S C$ s in the distal root stump of uninduced animals. $\boldsymbol{B}$, SCs in uninjured roots of induced animals are not increased. $\boldsymbol{C}$, Far more SCs are present in injured roots of induced animals. $\boldsymbol{D}$, Injured roots of induced animals contain $\sim 2$-fold more SCs than those of uninduced animals. Uninjured roots of induced animals do not show significant increase in SCS. $\boldsymbol{E}-\boldsymbol{H}$, Comparisons of proliferating SCS as identified by Ki-67 immunostaining. $\boldsymbol{E}$, Injured root of uninduced animals contains few Ki-67+SCS. F, Uninjured root of induced animals contains few proliferating SCS (arrow). $\boldsymbol{G}$, Injured root of induced animals contains far more proliferating $S C S$. $H$, Injured roots of induced animals contain $\sim 5$-fold more proliferating SCs than those of uninduced animals. $I-L$, Comparisons of $S C$ redifferentiation as analyzed by immunostaining for SC2E, which labels SC myelin. I, Injured roots of uninduced animals contain abundant SC2E immunoreactivity, showing substantial redifferentiation. J, Uninjured roots of induced animals reveal SC2E immunolabeling not noticeably different from those of uninduced animals (data not shown). $K$, Injured roots of induced animals reveal little SC2E immunolabeling. $\boldsymbol{L}$, Quantitative comparisons of SC myelin. $n=6$ mice per each group $(\boldsymbol{D}, \boldsymbol{H}, \boldsymbol{L}) ;(\boldsymbol{D}){ }^{* *} p=0.0078 ; \mathrm{df}=9,{ }^{* * *} p=0.0003 ; \mathrm{df}=9,{ }^{* * * *} p<0.0001 ; \mathrm{df}=9, \mathrm{n} . \mathrm{s} .=$ not-significant $(p=0.9968$; $\mathrm{df}=9) ;(\boldsymbol{H})^{* * * *} p<0.0001 ; \mathrm{df}=8$, n.s. $=$ not-significant $(p=0.9711$ or $0.3242 ; \mathrm{df}=8) ;(\boldsymbol{L}){ }^{* * * *} p<0.0001 ; \mathrm{df}=44$, n.s. $=$ not-significant $(p=0.9912 ; \mathrm{df}=44) ;$ one-way ANOVA with Tukey's multiple-comparison test. DH, Dorsal horn. Scale bar, $100 \mu \mathrm{m}$.

extent of myelination in intact roots of induced animals, as determined by SC2E immunoreactivity, was indistinguishable from that in intact roots of uninduced animals (Fig. $2 L$ ). These data show that post-injury induction of caErbB2 for 2 weeks does not evoke pronounced dedifferentiation or proliferation of innervated SCs in intact DR.

To investigate redifferentiation of denervated SCs, we also compared myelin expression in injured roots of induced and uninduced animals. As expected, DRs of uninduced animals revealed substantial SC2E immunoreactivity 2 weeks after root crush, indicating that $\mathrm{SCs}$ had begun to remyelinate regenerating DR axons (Fig. 2I). In contrast, myelin expression was significantly lower in injured roots of induced than of uninduced animals (Fig. $2 K, L$ ), indicating that far more SCs remained reactive (i.e., dedifferentiated). In summary, these findings show that post-injury SC-specific induction of caErbB2 selectively causes denervated, but not innervated, SCs to be "hyperreactive" after injury: their proliferation is increased and their dedifferentiation is prolonged.
Post-injury induction of caErbB 2 in SCs promotes DR regeneration through a transection injury

We next investigated whether SCs expressing caErbB2 can support regeneration of injured DRs. We first studied DR regeneration using a transection injury: L4 and L5 DRs of caErbB2 $\mathrm{cTg}$ mice were completely transected and $\sim 0.5 \mathrm{~mm}$ segments were removed from both roots (Fig. 3A, red arrow). After lifting the proximal stumps to confirm a complete transection, we closely apposed, but did not suture, the cut ends of proximal and distal stumps. We then injected AAV-GFP viruses to L4 and L5 DRGs to fluorescently label regenerating axons (Fig. $3 A$ ). After surgery, mice were fed Dox-containing food for 2 weeks. We then harvested and analyzed tissues in whole-mount preparations (Fig. $3 B ; n=6$ mice). In uninduced animals, as we reported earlier ( $\mathrm{Di}$ Maio et al., 2011), DR axons rarely penetrated the $>0.5 \mathrm{~mm}$ gap at the transection site, which was filled with extensive fibrous scar tissue (Fig. 3B, \#1). In marked contrast, in induced animals, many more axons traversed the transection site and extended further along the root (Fig. $3 B, \# 2, \# 3$ ). It was also notable that, although 
A

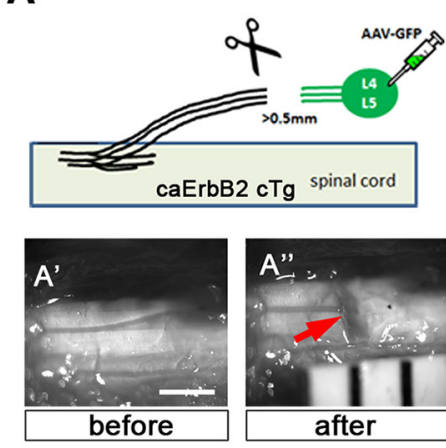

C

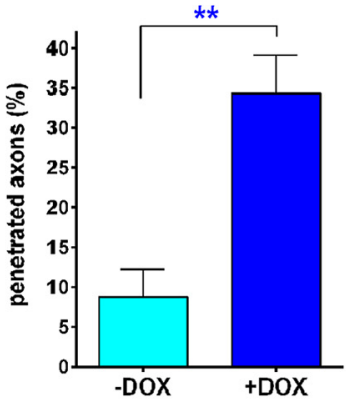

B
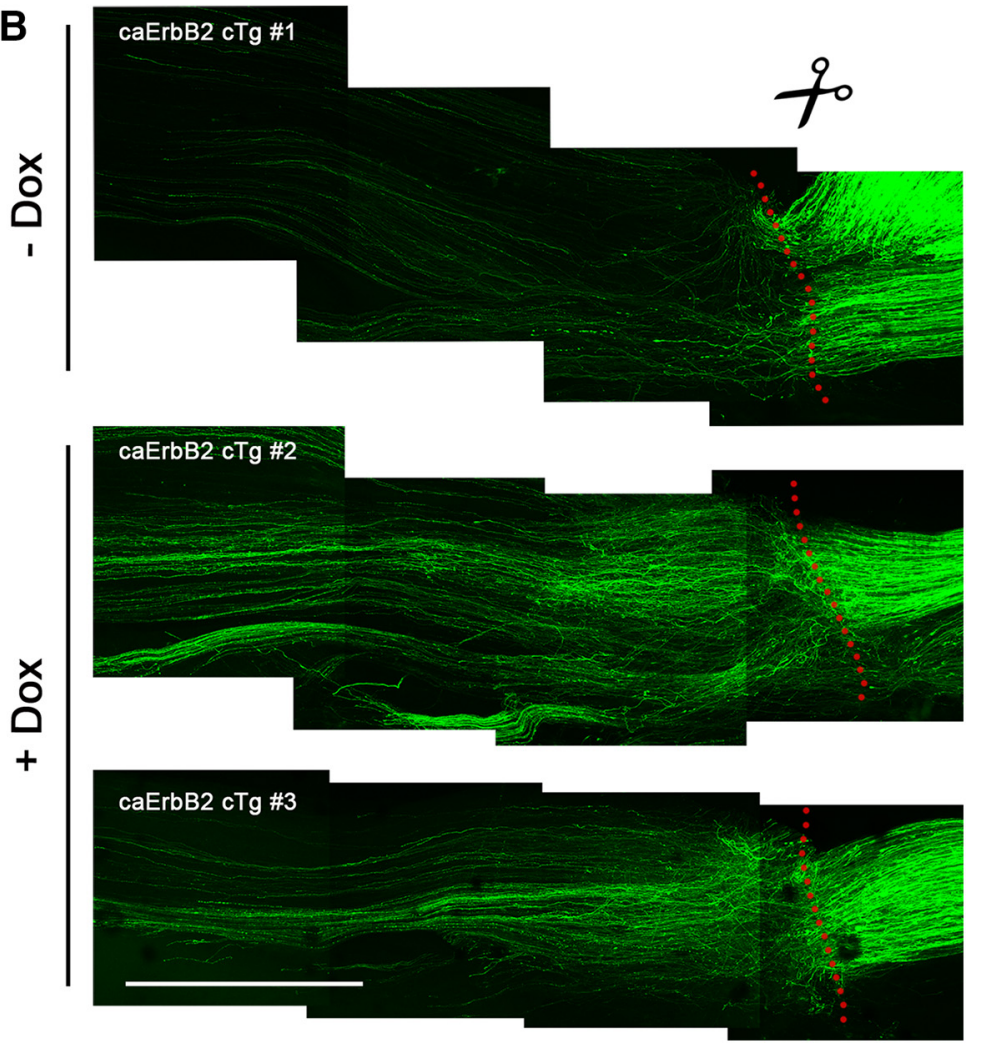

Figure 3. Enhanced DR regeneration through a transection injury. A, Diagram illustrating nerve transection and fluorescent labeling of regenerating axons. $L 4$ and L5 DRs of caErbB2 cTg mice were completely transected by removing $\sim 0.5 \mathrm{~mm}$ segments (red arrow). $\boldsymbol{A}^{\prime}, \boldsymbol{A}^{\prime \prime}$, The transection site before and after complete transection. Regenerating axons are fluorescently labeled by injecting AAV-GFP viral vectors into the DRGs. $\boldsymbol{B}$, Whole mounts of DRs were prepared 2 weeks after transection. Red dotted lines indicate transection site. Far more numerous axons penetrate the transection site and extend further along the distal root stump in induced animals than in uninduced animals. $C$, The number of axons that penetrate the transection site increases $\sim 3$-fold in induced animals; $n=8$ mice per each group. ${ }^{* *} p=0.0055 ; \mathrm{df}=6$; unpaired Student's $t$ test. Scale bars: $A, B, 1 \mathrm{~mm}$.

the number of axons that penetrated the transection site increased only $\sim 3$-fold in induced animals (Fig. $3 C$ ), many more axons were present distally and grew longer distances along the root (Fig. 3B). This is likely due to extensive regenerative sprouting of axons within the roots distal to the transection sites (see below; Chen and Brushart, 1998; Matsumoto et al., 1999). Thus, post-injury induction of caErbB2 in SCs greatly improved DR regeneration after transection injury.

Post-injury induction of caErbB2 in SCs enhances regenerative sprouting and axon regeneration following a crush injury

Next, we analyzed the regenerative responses of SCs and axons after crush injury of cervical roots of caErbB2 cTg mice. Following unilateral C5-C8 DR crush injury, we fed the animals with Dox-containing food for 2 weeks, then harvested and analyzed tissues in transverse sections (Fig. 4). The first striking feature of caErbB2-induced animals was pronounced expansion of the crushed roots; they were twice as thick as the crushed roots of uninduced animals (Figs. $4 A, C, 5$ ) and contained $\sim 4$-fold more SCs (Fig. 2C,D). Notably, p75 antibody immunostaining revealed an $\sim 2$-fold increase in cellular processes extended by SCs (Fig. $4 A, B$ ) in the crushed roots of induced animals compared to those of uninduced animals (Fig. $4 F$ ).

Double immunostaining with neurofilament (NF) antibody revealed that far more $\mathrm{NF}+$, proprioceptive and mechanoreceptive axons extended along the root in tight association with p75+ $\mathrm{SC}$ processes in induced animals (Figs. $4 A, D$ ). A greater number of CGRP + nociceptive axons also extended along SC processes distal to the crush injury in induced animals (Fig. $4 B, E$ ), indicating that caErbB2 greatly enhances regenerative sprouting of diverse types of DRG axons and supports their extension along the root.

SCs extend long, thin cellular processes in response to denervation (Son and Thompson, 1995a; Gomez-Sanchez et al., 2017), which induce and guide regenerative axon sprouts (Son and Thompson, 1995b). The observation that far more axons are induced to form and grow along caErbB2 SC processes suggests that caErbB2 SCs, which exhibit increased proliferation and prolonged dedifferentiation, are repair SCs capable of promoting axon outgrowth. The striking DR expansion indicates extraordinary migration of hyperreactive caErbB2 SCs and extension of their processes outside the usual growth pathways provided by pre-existing basal lamina tubes in the distal stumps, followed by extraordinary axon outgrowth.

\section{Axons and SCs remain quiescent in intact roots of caErbB2-induced animals}

To be clinically applicable, an experimental strategy must cause minimal off-target effects. We therefore carefully assessed the contralateral intact DRs of the induced animals. Two weeks after DR crush, the contralateral intact roots of the induced animals appeared normal in size (Fig. 5A-D), unlike the much-expanded ipsilateral crushed roots (Fig. $5 A^{\prime}-D^{\prime}$ ). They contained no axons immunopositive for the small proline-rich repeat protein $1 \mathrm{~A}$ (SPRR1A), which marks sprouting or regenerating axons (Bonilla et al., 2002; Starkey et al., 2009). We also investigated if intact DRs of induced animals contain short nascent axon sprouts. We used caErbB2-YFPH cTg mice in which subsets of NF+, largediameter DRG axons are brightly labeled by YFP fluorescence 

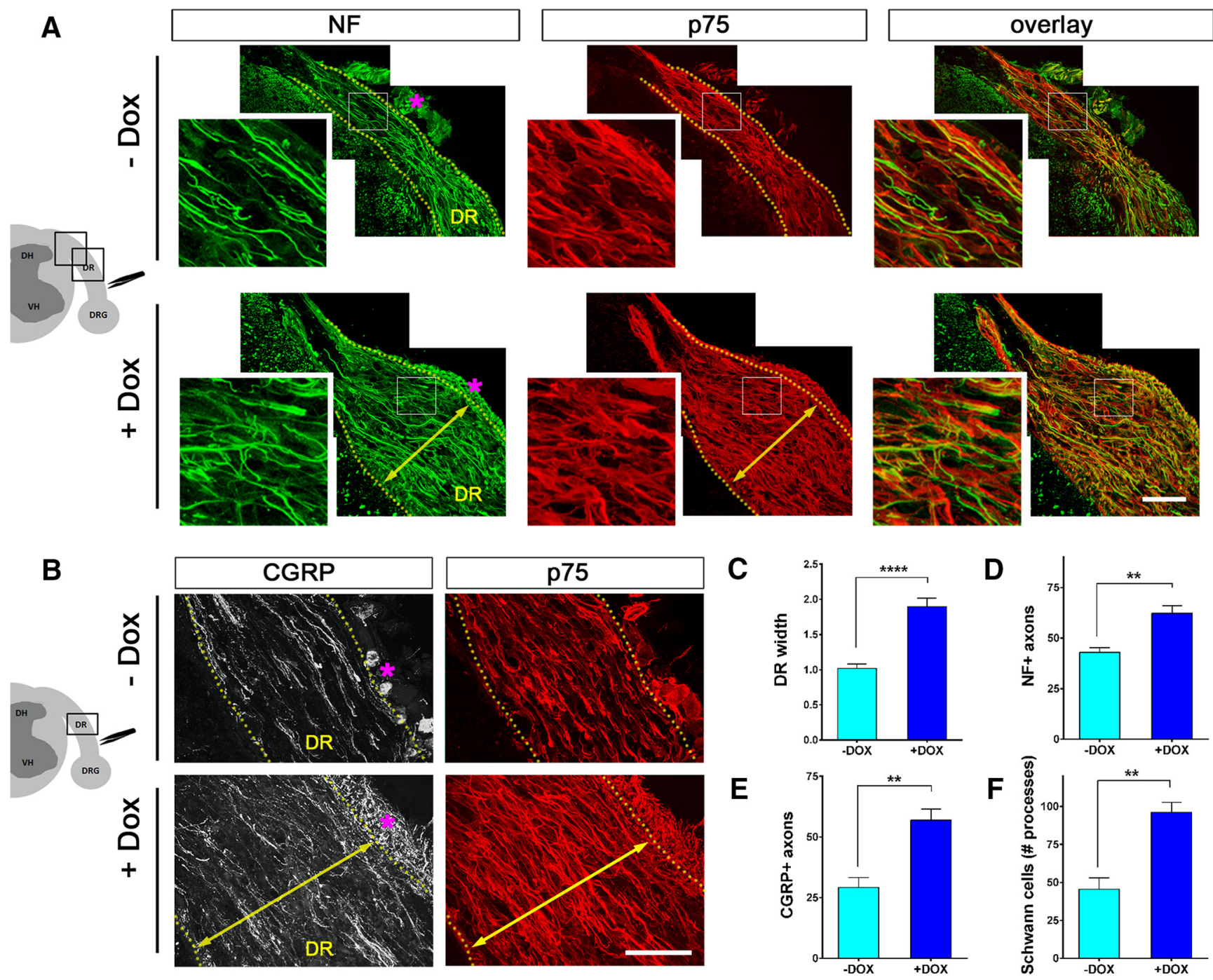

Figure 4. Enhanced DR regeneration following crush injury. A, Transverse sections of cervical roots of uninduced and induced caErbB2 cTg mice 2 weeks after root crush. Axons are immunolabeled by a NF antibody. SCs are immunolabeled by p75 antibody. Crushed roots of induced animals are substantially enlarged and contain far more numerous axons and SC processes than those of uninduced animals. Axons extend in tight association with SC processes in induced and uninduced animals. B, Immunolabeling of transverse sections with a CGRP antibody and a p75 antibody shows far more numerous CGRP + axons regenerated along the distal root stump in induced animals. $C$, Injured roots of induced animals are twice as thick as the crushed roots of uninduced animals. ${ }^{* * * *} p<0.0001 ; \mathrm{df}=17$; unpaired Student's $\mathrm{t}$ test. $n>6$ mice per each group. $\boldsymbol{D}$, Injured roots of induced animals contain $\sim 30 \%$ more NF + axons than injured roots of uninduced animals. ${ }^{* *} p=$ $0.0051 ; \mathrm{df}=6$; unpaired Student's $t$ test. $n>6$ mice per each group. $E$, Injured roots of induced animals contain $\sim 100 \%$ more CGRP + axons than injured roots of uninduced animals. ${ }^{* *} p=$ $0.0037 ; \mathrm{df}=6$; unpaired Student's $\mathrm{t}$ test. $n>6$ mice per each group. $\boldsymbol{F}$, Injured roots of induced animals contain $\sim 100 \%$ more $S$ C processes than injured roots of uninduced animals. ${ }^{* *} p=0.0021$; $\mathrm{df}=6$; unpaired Student's $t$ test. $n>6$ mice per each group. Asterisks $\left(^{*}\right)$ in $\boldsymbol{A}$ and $\boldsymbol{B}$ denote immunolabeling of fibrous connective tissue that is not specific. Scale bar, $100 \mu \mathrm{m}$.

(Di Maio et al., 2011). NF+ (i.e., YFP+) axons in contralateral intact roots appeared normal 2 weeks after DR crush. We found no signs of axon degeneration and no axon sprouts extended from the nodes (Fig. $5 E ; n>3$ mice).

Unmyelinated CGRP + DR axons sprout and regenerate more robustly than myelinated NF+ axons (Nakamura and Myers, 2000; Lin et al., 2014; Kelamangalath et al., 2015). We therefore looked for CGRP+ axon sprouting in intact roots of induced animals (Fig. 5F). Whereas CGRP+ immunoreactivity was consistently thin and punctate in uninduced animals, the label was thicker in occasional intact roots of induced animals, indicating axon sprouting (Fig. $5 F$ ). The sprouting of CGRP+ axons was infrequent, however, and analysis of transverse sections showed that the thickened CGRP label was no longer than the punctate labeling in intact roots of uninduced animals.

Consistent with minimal if any axonal alterations, neither p75 nor GFAP immunoreactivity was upregulated in intact roots (Fig.
$5 B, C)$, whereas, in sharp contrast, immunoreactivity for both was robust in crushed roots of induced animals (Fig. $5 B^{\prime}, C^{\prime}$ ). Both p75 and GFAP are normally expressed by non-myelinating SCs but upregulated after injury in all denervated or dedifferentiated SCs (Gai et al., 1996; Triolo et al., 2006). Taken together with the occurrence of little if any proliferation of SCs in intact roots (Fig. $2 B, F$ ), this result is further evidence that post-injury induction of caErbB2 remarkably enhances reactivity of denervated SCs to injury, while SCs in intact roots remain quiescent.

\section{caErbB2 promotes restricted penetration of axons and SCs} across the DREZ

Our results thus far suggest that caErbB2 enhances proliferation and dedifferentiation of selectively denervated SCs, and augments axon regrowth along the injured DR. The crucial challenge to regenerating DR axons is to penetrate the DREZ and extend deeper into the spinal cord. SCs are also precluded from migrat- 

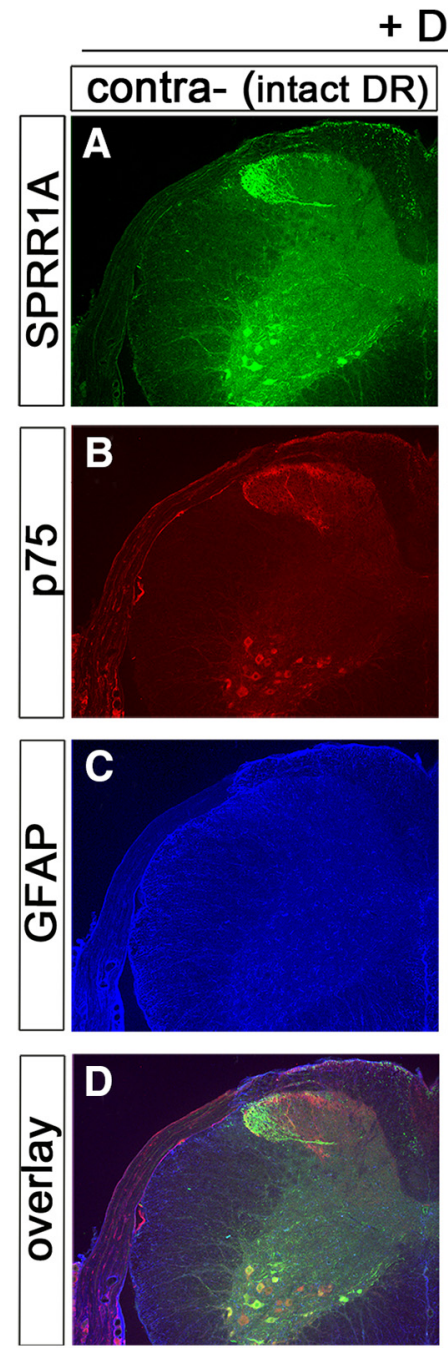

\section{Dox}
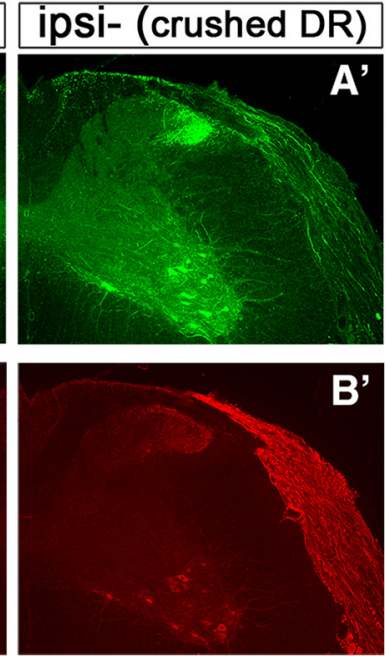

B'
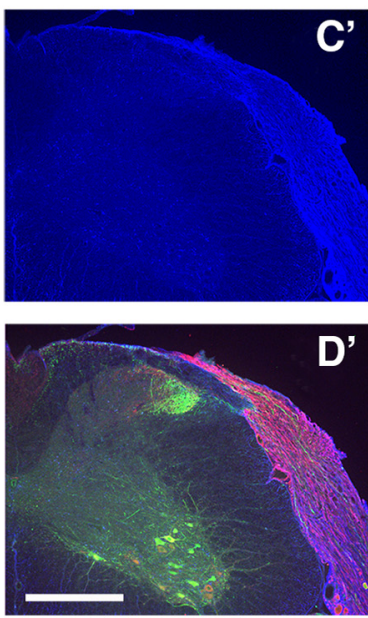

E

E, F

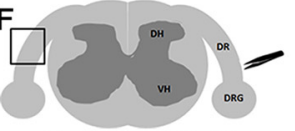

caErbB2-YFPH cTg

+ Dox

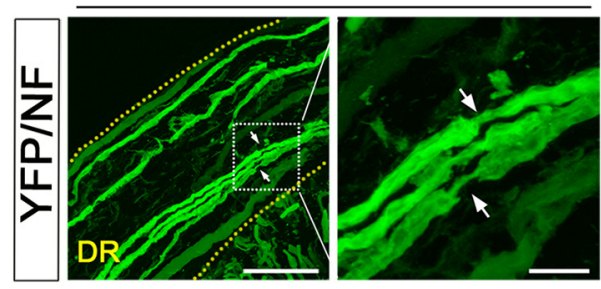

F

- Dox
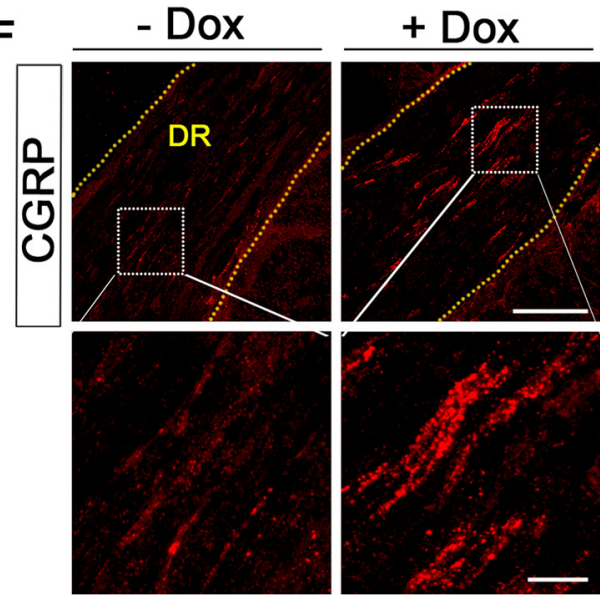

Figure 5. Axons and SCs remain quiescent in uninjured roots. $\boldsymbol{A}-\boldsymbol{F}$, Triple immunostaining of a transverse section of spinal cord of an induced caErbB2 cTg animal 2 weeks after DR crush. $\boldsymbol{A}, \boldsymbol{A}^{\prime}$, SPRR1A immunoreactivity in contralateral uninjured roots $(\boldsymbol{A})$ is sparse, as in uninduced animals (data not shown), suggesting induction of little if any axon sprouting. Many regenerating axons in ipsilateral injured roots of the same animal $\left(\boldsymbol{A}^{\prime}\right)$ are highly immunopositive for SPRR1A. $\boldsymbol{B}, \boldsymbol{B}^{\prime}$, p75 immunoreactivity, presumably associated with non-myelinating SCS, is moderate in uninjured roots ( $\boldsymbol{B})$, as in uninduced animals (data not shown), whereas that in injured roots is robust $\left(\boldsymbol{B}^{\prime}\right)$. $\boldsymbol{C}, \boldsymbol{C}^{\prime}$, GFAP immunoreactivity in uninjured root $(\boldsymbol{C})$ is as low as in uninduced animals (data not shown), whereas it is robust in injured roots $\left(\boldsymbol{C}^{\prime}\right)$. Note that bleed-through of strong, dense 75 labeling further enhances the upregulated GFAP labeling, which gives the false impression of stronger GFAP labeling in the PNS than CNS in $\boldsymbol{C}^{\prime} . \boldsymbol{D}, \boldsymbol{D}^{\prime}$, Merged images of $\boldsymbol{A}-\boldsymbol{C}^{\prime}$. $\boldsymbol{E}, \mathrm{NF}+$ axons do not sprout in uninjured roots, as analyzed by close examination of nodes of Ranvier in induced caErbB2-YFPH cTg 2 weeks post-crush injury ( $n>50$ nodes, 3 mice). Arrows indicate examples of nodes without axon sprouts. $F$, GGRP immunolabeling in some transverse sections appears thicker in uninjured roots of induced animals. Thicker (GRP labeling likely represents moderate sprouting of non-myelinated CGRP + axons. Scale bars: $\boldsymbol{A}-\boldsymbol{D}^{\prime}, 300 \mu \mathrm{m} ; \boldsymbol{E}$, left, $100 \mu \mathrm{m} ; \boldsymbol{E}$, right, $50 \mu \mathrm{m} ; \boldsymbol{F}$, top, $100 \mu \mathrm{m} ; \boldsymbol{F}$, bottom, $50 \mu \mathrm{m}$.

ing across the DREZ (Grimpe et al., 2005). We next investigated whether SCs and/or axons were able to penetrate the DREZ in induced animals. Two weeks after DR crush, in uninduced caErbB2 cTg mice, SCs and astrocytes formed the characteristic domeshaped border, convexity oriented peripherally, where the two cell types abutted each other at the DREZ (Fig. 6A). In contrast, in induced animals, the astrocyte-SC border formed more centrally, in the territory of the astrocytes (Fig. $6 B, C^{\prime \prime \prime}, D^{\prime \prime \prime}$ ), indicating that SCs had penetrated the area where the border is typically established. Those axons located in the CNS were tightly associated with SCs (Fig. $6 C, D$ ). Notably, however, both SCs and axons in the CNS extended dorsally toward the growth-permissive dura mater (Fig. $\left.6 C-C^{\prime}, D-D^{\prime}\right)$, rather than toward spinal cord parenchyma. This observation suggests that the invasion of SCs and axons into the spinal cord continues to be restricted despite robustly enhanced outgrowth along the roots in caErbB2-induced animals.

In induced animals, CGRP + axons also penetrated the DREZ in association with caErbB2 SC processes, but grew dorsally to- ward the dura mater, similarly restricting their intraspinal regeneration (Fig. $6 E-E^{\prime \prime}$ ). Only occasionally did a few CGRP+ axons extend toward the dorsal horn independent of caErbB2 SCs (Fig. $6 E$, arrows). These results demonstrate that post-injury induction of caErbB2 in SCs promotes migration of SCs and axon regeneration into the spinal cord, but the effect is modest.

\section{Supplementary removal of CSPGs fails to drive robust} penetration of SCs and axons across the DREZ

We next tested strategies to generate robust penetration of DR axons and/or migration of caErbB2-expressing SCs deep into the spinal cord in induced animals. Astrocytes form tight interfaces with SCs at the DREZ. Removal of chondroitin sulfate proteoglycans (CSPGs) promotes intermingling of SCs and astrocytes both in vitro and in vivo (Grimpe et al., 2005; Afshari et al., 2010). In addition, treatment of experimental spinal cord injuries with chondroitinase in conjunction with SC or peripheral nerve grafts promotes axonal regrowth across the SC-astrocyte interfaces 


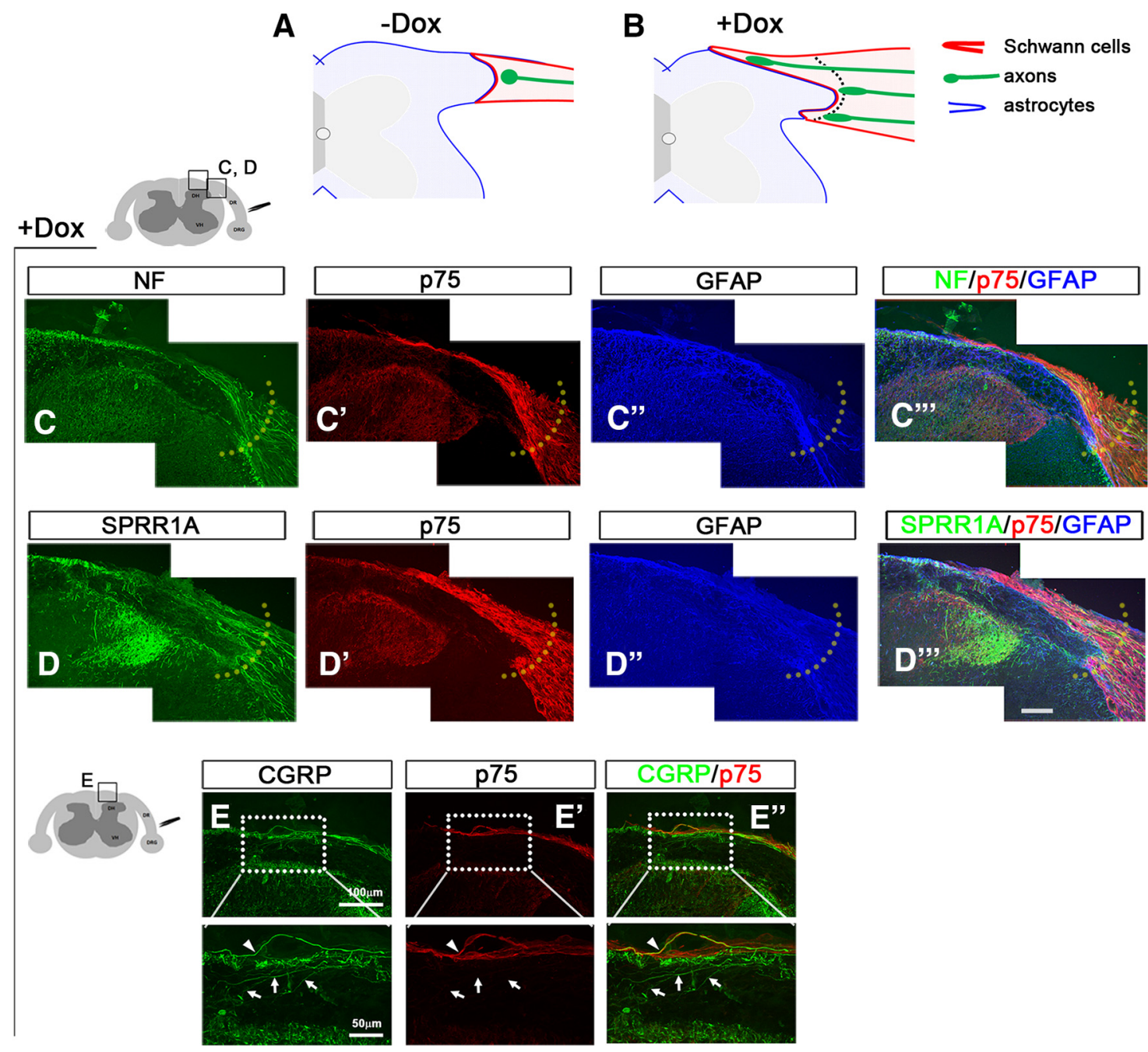

Figure 6. Improved but restricted penetration of axons and SCs across the DREZ. The patterns of SC migration and axon regeneration across the DREZ in injured roots of uninduced $(\boldsymbol{A})$ and induced $\left(\boldsymbol{B}-\boldsymbol{E}^{\prime \prime}\right)$ CaErbB2 cTg 2 weeks post-crush injury. A, Diagram illustrating a characteristic convex, dome-shaped borderline where astrocytes and SCs abut at the DREZ in uninduced animals. Light blue area denotes CNS territory populated by astrocytes; light red area, PNS territory populated by SCS. B, Diagram summarizing the results presented in $\boldsymbol{C}-\boldsymbol{E}^{\prime \prime}$; penetration of SCs and axons across the DREZ is improved in induced animals but limited by extending dorsally toward growth-permissive dura mater. C-C'", NF + axons penetrate the DREZ but extend dorsally in association with p75 + SCs. GFAP immunostaining denotes the newly formed border between SCs and astrocytes. D-D'"', Another induced animal in which regenerating axons immunolabeled by a SPRR1A antibody show a similarly restricted penetration of axons and SCS. $\boldsymbol{E}-\boldsymbol{E}^{\prime \prime}, \mathrm{A}$ few CGRP + axons on dorsal dura (arrowhead) extend ventrally (arrows) toward the dorsal horn independently of $S C$ processes. Scale bars: C-D"', $100 \mu \mathrm{m} ; \boldsymbol{E}$, top, $100 \mu \mathrm{m} ; \mathbf{E}$, bottom, $50 \mu \mathrm{m}$.

(Fouad et al., 2005; Grimpe et al., 2005; DePaul et al., 2015). We therefore tested whether removal of CSPGs might enable robust SC migration and/or axonal regrowth into the spinal cord in induced animals ( $n=6$ mice). To remove CSPGs, we injected lentiviruses expressing chondroitinase ABC (LV-chABC; Curinga et al., 2007; Jin et al., 2011) into the dorsal horn near the DREZ at the time of root crush. Two weeks later, we used CS56 antibody immunostaining to confirm that LV-chABC effectively removed the inhibitory sulfated glycosaminoglycan chains on CSPGs (Fig. 7 B, C). In uninduced animals, consistent with earlier reports (Steinmetz et al., 2005; Wu et al., 2016), CSPG removal alone did not enable SCs or DR axons to regenerate across the DREZ (Fig. $\left.7 B-b^{\prime \prime \prime}\right)$. Likewise, in induced animals that received LV-chABC, no axons or SCs regenerated deep into the spinal cord (Fig. $\left.7 C-c^{\prime \prime \prime}\right)$. Instead, as in induced animals untreated with LV-chABC (Fig. 7A- $a^{\prime \prime \prime}$ ), axons and SCs extended dorsally toward dura mater and penetration across the DREZ was limited. Thus, supplementary removal of CSPGs does not facilitate migration or penetration of SCs or axons across the DREZ in the induced caErbB2 cTg mice.
Supplementary GDNF treatment drives robust intraspinal penetration of SCs and axons across the DREZ

Intraspinal expression of neurotrophic factors promotes penetration of regenerating DR axons across the DREZ (Kelamangalath et al., 2015; Liu et al., 2016). When expressed virally within the spinal cord, GDNF enhances intraspinal regeneration of largediameter DR axons (Deng et al., 2013; C. Zhang et al., 2013; Kelamangalath et al., 2015). GDNF has also been suggested to stimulate SC migration and proliferation (Höke et al., 2003; Iwase et al., 2005; L. Zhang et al., 2009). To test whether intraspinal expression of GDNF enhances penetration of axons and/or SCs into the spinal cord in induced caErbB2 cTg mice, we microinjected lentiviruses expressing GDNF (LV-GDNF) into the dorsal horn near the DREZ at the time of DR crush (Fig. 8A). To fluorescently label regenerating DR axons, we injected AAV-GFP viruses into DRGs. Two weeks after the crush, numerous axons penetrated the DREZ in uninduced animals that had received LV-GDNF (Fig. $8 B, C, G$ ). SCs did not accompany DR axons past the DREZ in these animals (Fig. $8 B^{\prime}, C^{\prime}$ ). Remarkably, in induced animals that had received LV-GDNF (Fig. $8 D-E^{\prime \prime \prime}$ ), nearly all of 

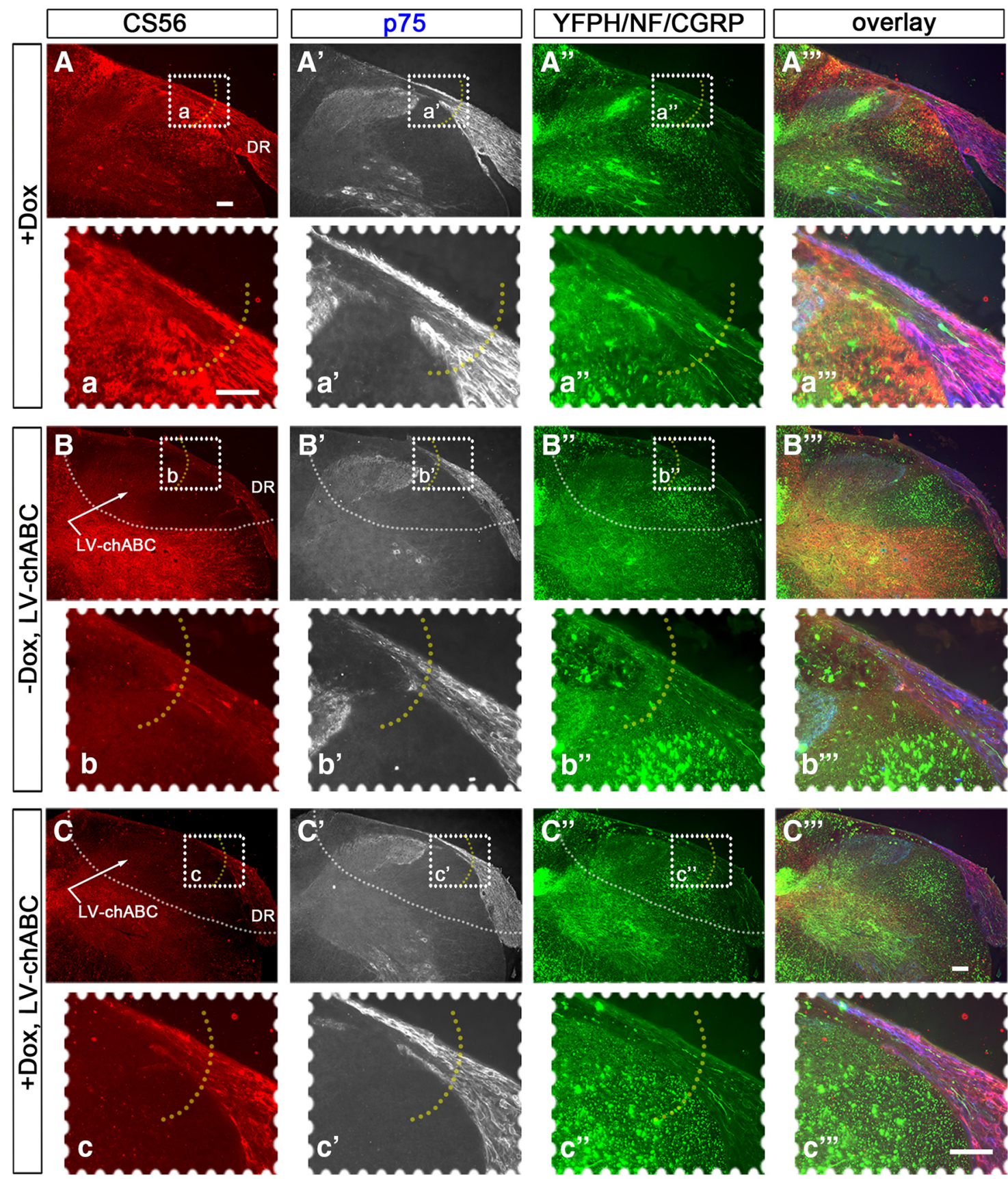

Figure 7. Effects of supplementary CSPG removal in induced caErbB2 cTg mice. $\boldsymbol{A}-\boldsymbol{A}^{\prime \prime \prime}$, A transverse section of injured roots of an induced caErbB2-YFPH cTg 2 weeks post-crush injury. CSPGs, revealed by CS56 antibody immunostaining, are abundant around the DREZ. $\boldsymbol{a}-\boldsymbol{a}^{\prime \prime \prime}$, Enlarged views of boxed area at the DREZ in $\boldsymbol{A}-\boldsymbol{A}^{\prime \prime \prime}$. Axons immunolabeled by NF and CGRP antibodies in addition to YFP + axons. $\boldsymbol{B}-\boldsymbol{B}^{\prime \prime \prime}$, A transverse section of injured roots of an uninduced caErbB2-YFPH cTg which received LV-chABC at the time of root crush. CS56 immunoreactivity ( $\boldsymbol{B}$ ) confirms effective removal of CSPGs from the DREZ and dorsal horns. No migration of SCS $\left(\boldsymbol{B}^{\prime}\right)$ or axonal regeneration $\left(\boldsymbol{B}^{\prime \prime}\right)$ is observed across the DREZ. $\boldsymbol{b}-\boldsymbol{b}^{\prime \prime \prime}$, Enlarged views of boxed area in $\boldsymbol{B}-\boldsymbol{B}^{\prime \prime \prime}$. $\boldsymbol{C}-\boldsymbol{C}^{\prime \prime}$, Even in induced animals which received LV-chABC, CSPG removal $(\boldsymbol{C})$ does not promote migration of SCs $\left(\boldsymbol{C}^{\prime}\right)$ or axonal regeneration $\left(\boldsymbol{C}^{\prime \prime}\right)$ into the spinal cord. $\boldsymbol{C}-\boldsymbol{C}^{\prime \prime \prime}$, Enlarged views of boxed area in $\boldsymbol{C}-\boldsymbol{C}^{\prime \prime \prime}$. Note that, due to far brighter YFP fluorescence than immunofluorescence, YFP-negative axons immunolabeled by NF or CGRP antibodies are under-represented even in magnified images ( $\boldsymbol{a}^{\prime \prime}, \boldsymbol{b}^{\prime \prime}$, $\left.c^{\prime \prime}\right) . n=6$ mice per group. Scale bar, $100 \mu \mathrm{m}$.

the GFP+ axons penetrated the DREZ and extended deep into the spinal cord (Fig. 8D,E,G). A very large number of SCs and their processes also penetrated the DREZ (Fig. $8 D^{\prime}, E^{\prime}$ ) and accompanied DR axons within the spinal cord (Fig. $8 D^{\prime \prime \prime}, E^{\prime \prime \prime}, F, G$ ). Thus, in combination with caErbB2 induction, GDNF enabled far more axons to penetrate the DREZ by promoting massive migration of caErbB2 SCs and their processes into the spinal cord. SCs that migrated into the spinal cord were not intermingled with astrocytes (Fig. 8D", $\mathrm{E}^{\prime \prime}$ ). Instead, astrocytes formed a new astrocyte-SC interface deep in the spinal cord.
NCAM, Ret, and c-Jun expression in caErbB2 SCs

Intraspinally expressed GDNF enabled intraspinal migration of SCs selectively in induced animals, suggesting that caErbB2 enhanced SC responsiveness to extracellular GDNF. GDNF binds to the GDNF family receptor $\alpha-1$ (GFR $\alpha 1$ ), which signals by activating the Ret tyrosine kinase. In Ret-negative cells, NCAM mediates transmembrane signaling of GFR $\alpha$ receptors (Paratcha et al., 2003). SCs express GFR $\alpha 1$ and NCAM, but not Ret (Naveilhan et al., 1997; Trupp et al., 1997). We examined whether caErbB2expressing SCs might upregulate Ret expression to transduce GNDF 

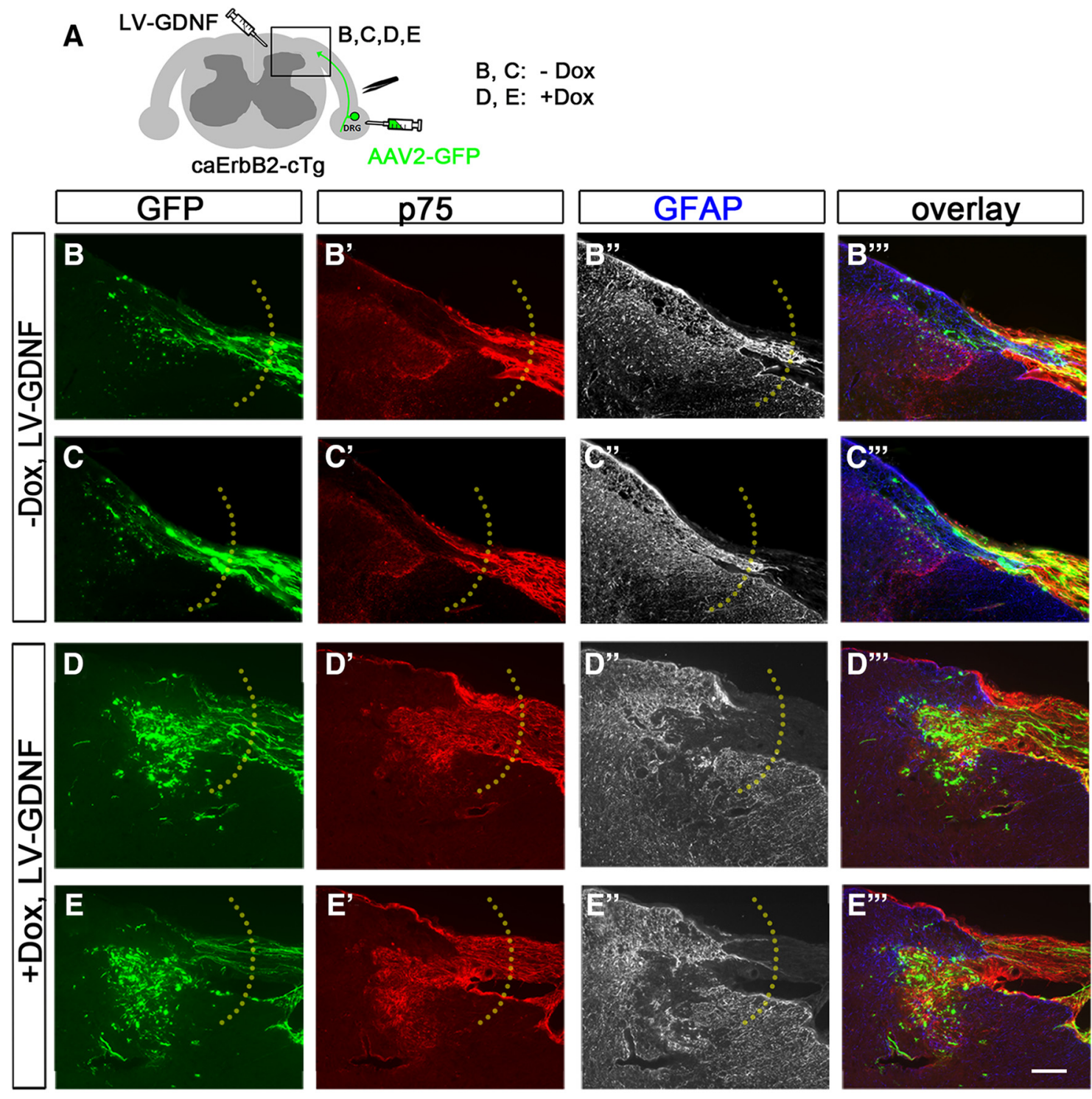

$\mathbf{F}$
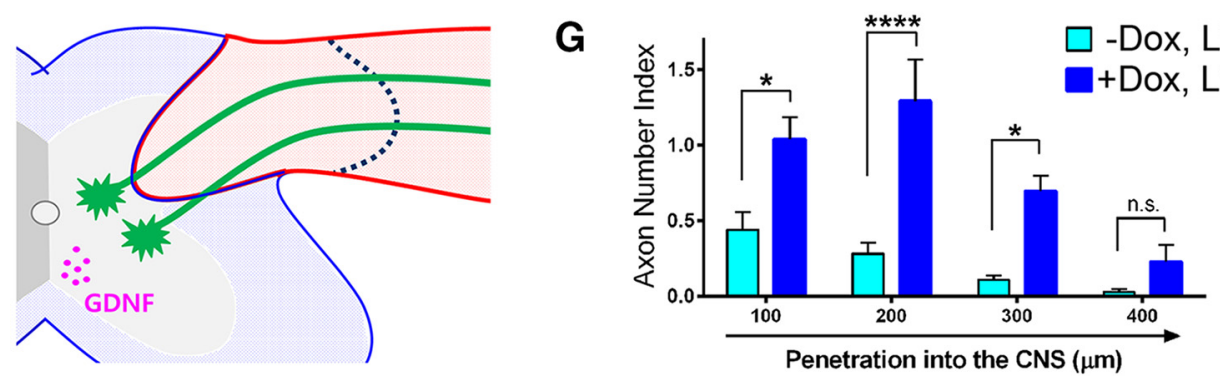

Figure 8. Effects of supplementary GDNF in induced caErbB2 cTg mice. A, Diagram showing the experimental scheme. After DR crush, LV-GDNF was injected into the dorsal horn near the DREZ and AAV2-GFP was injected into DRGs to label regenerating axons. $\boldsymbol{B}-\boldsymbol{C}^{\prime \prime}$, Two representative images of uninduced animals that received LV-GDNF, showing axons, SCS, and astrocytes at the DREZ 2 weeks post-crush injury. Numerous axons penetrate the DREZ $(\boldsymbol{B}, \boldsymbol{C})$, whereas $S C$ s do not $\left(\boldsymbol{B}^{\prime}, \boldsymbol{C}^{\prime}\right)$. SCs and astrocytes $\left(\boldsymbol{B}^{\prime \prime}, \boldsymbol{C}^{\prime \prime}\right)$ abut where they typically form a borderline. $\boldsymbol{D}-\boldsymbol{E}^{\prime \prime \prime}$, Two representative images of induced animals that received LV-GDNF. Far more axons $(\boldsymbol{D}, \boldsymbol{E})$ penetrate the DREZ and extend further into the spinal cord, in association with SCS $\left(\boldsymbol{D}^{\prime}, \boldsymbol{E}^{\prime}\right)$.SCs and astrocytes $\left(\boldsymbol{D}^{\prime \prime}, \boldsymbol{E}^{\prime \prime}\right)$ form a new borderline deep in the dorsal horn. $F$, Diagram summarizing the effects of GDNF. Intraspinal expression of GDNF promotes intraspinal migration of caErbB2-expressing SCS, enabling massive penetration of axons across the DREZ. G, Quantitative comparison of intraspinal axon regeneration in LV-GDNF injected, induced versus uninduced animals. Nearly all axons penetrate the DREZ in induced animals that received LV-GDNF. $100 \mu \mathrm{m}:{ }^{*} p=0.0121, \mathrm{df}=32 ; 200 \mu \mathrm{m}:{ }^{* * *} p<0.0001, \mathrm{df}=32 ; 300 \mu \mathrm{m}:{ }^{*} p=0.0145, \mathrm{df}=32 ; 400 \mu \mathrm{m}: \mathrm{n} . \mathrm{s}$. $=$ not significant $(p=0.7606, \mathrm{df}=$ 32); two-way ANOVA with Sidak's multiple comparison test. $n=6$ mice per each group. Scale bars, $100 \mu \mathrm{m}$.

signaling in induced caErbB2 cTg mice. Western blotting did not reveal increased expression of Ret proteins in the roots distal to crush in induced animals (Fig. 9A). Expression of NCAM was upregulated (Fig. 9A), however, and immunoreactivity was no- ticeably increased in SCs of crushed roots in induced animals (Fig. 9B). This finding suggests that GDNF promoted SC migration into the spinal cord in part by signaling through NCAM upregulated in caErbB2 SCs. 
A
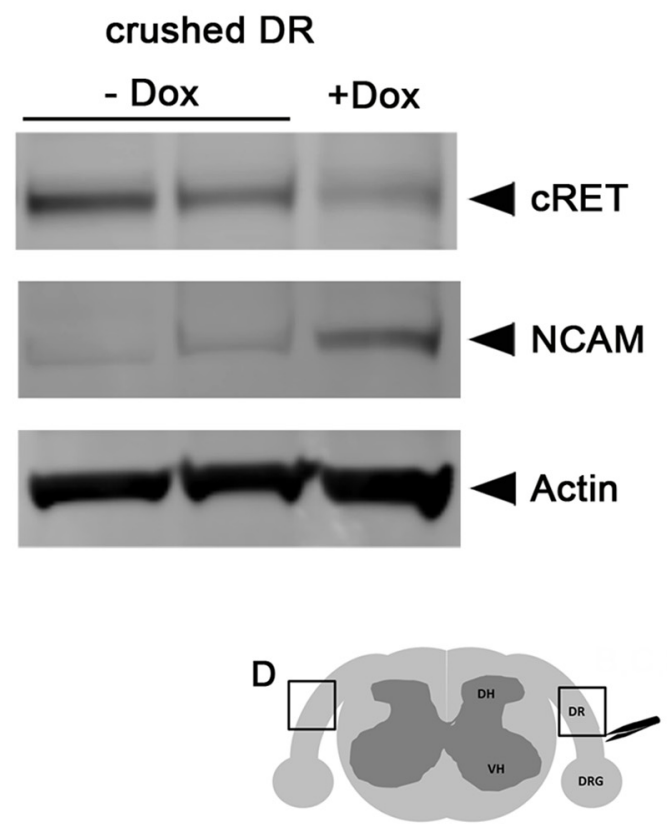

B
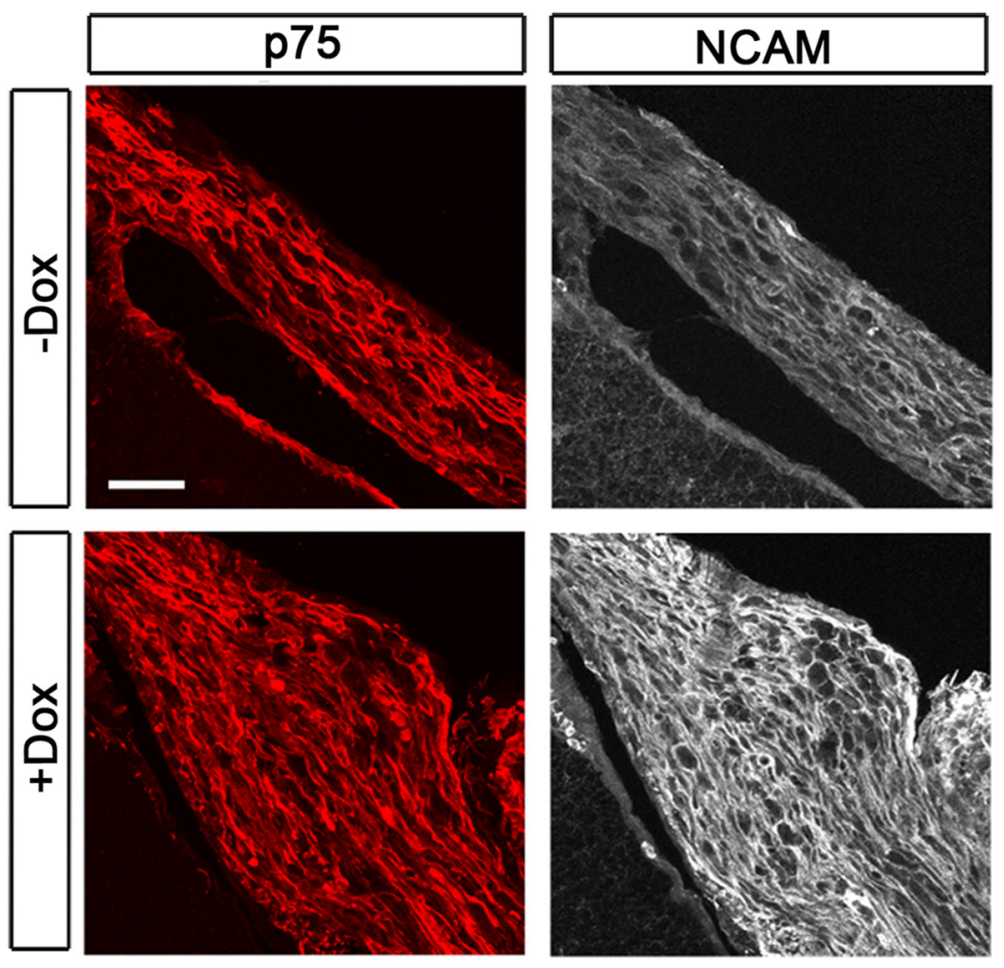

- Dox

+ Dox
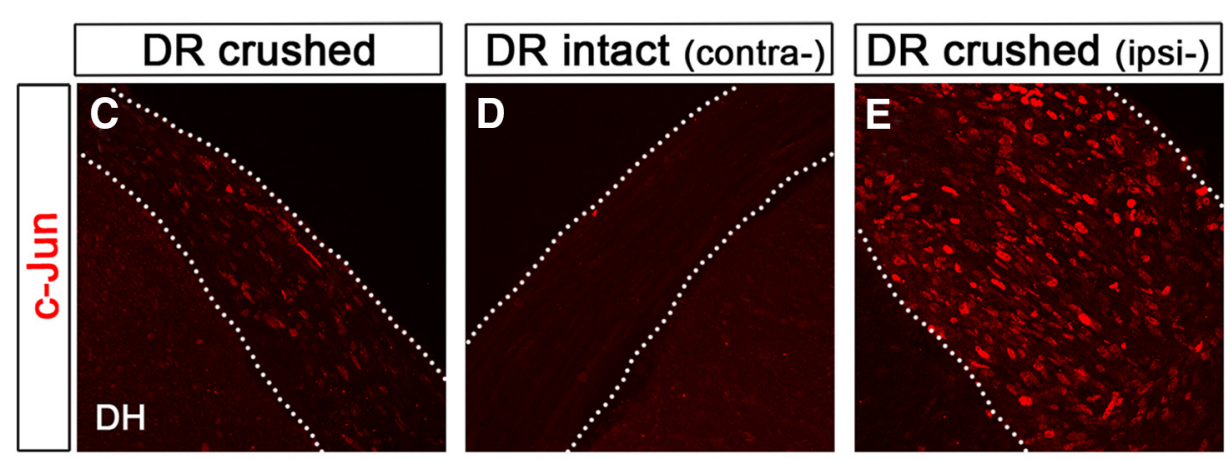

$\mathbf{F}$
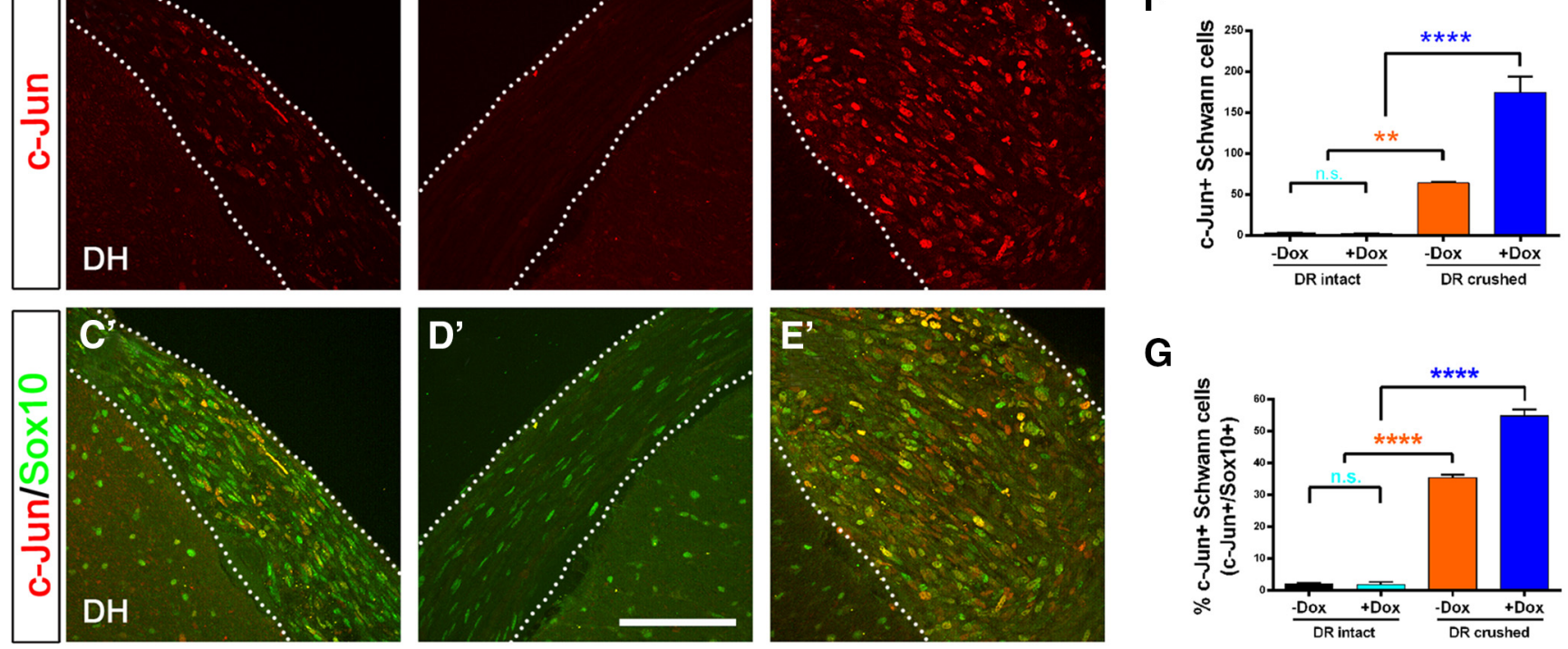

G

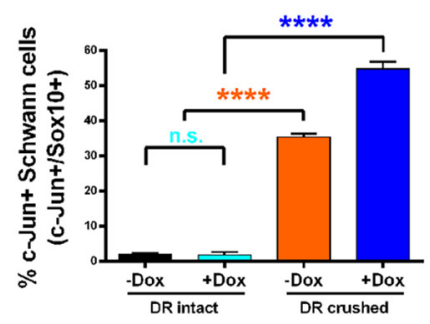

Figure 9. NCAM, Ret and c-Jun expression in caErbB2 SCS. Western blot and immunohistochemical analyses of DRs distal to root crush, 2 weeks post-injury in uninduced and induced caErbB2 cTg mice. $\boldsymbol{A}$, Western blot analysis shows upregulation of NCAM, but not CRET, in induced animals. $\boldsymbol{B}$, Immunohistochemical analysis shows stronger NCAM immunoreactivity in injured roots of induced animals, which is associated with SCs and processes immunolabeled by $p 75$ antibody. $\boldsymbol{C}, \boldsymbol{C}^{\prime}$, Injured roots of uninduced animals contains a number of $\mathbf{C}-$ Jun $+\boldsymbol{S C S}$. $\boldsymbol{D}-\boldsymbol{D}^{\prime}$, Uninjured roots of induced

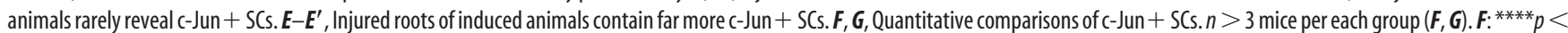
$0.0001 ; \mathrm{df}=13,{ }^{* *} p=0.0096 ; \mathrm{df}=13$, n.s. $=$ not significant $(p=0.9999 ; \mathrm{df}=13) ; G:{ }^{* * *} p<0.0001 ; \mathrm{df}=13$, n.s. $=$ not significant $(p=0.9996 ; \mathrm{df}=13) ;$ one-way ANOVA with Tukey's multiple comparison test. DH, Dorsal horn. Scale bars: $\boldsymbol{B}, 50 \mu \mathrm{m} ; \boldsymbol{C}-\boldsymbol{E}^{\prime}, 100 \mu \mathrm{m}$.

Last, we examined expression of c-Jun, a key transcription factor that is upregulated in denervated SCs, which enables the transdifferentiation of denervated SCs to repair SCs (Parkinson et al., 2008; Arthur-Farraj et al., 2012; Fontana et al., 2012). At 2 weeks after crush injury, a number of SCs remained immunopo- sitive for c-Jun in crushed roots of uninduced animals (Fig. $\left.9 C, C^{\prime}\right)$. In contrast, c-Jun + SCs were rare in intact roots of induced animals (Fig. 9D, $D^{\prime}$ ) and of uninduced animals (data not shown). Remarkably, crushed roots of caErbB2-induced animals showed far more SCs that were strongly immunopositive for 
c-Jun than crushed roots of uninduced animals (Fig. 9E, $E^{\prime}, F$ ). Counts of c-Jun + SCs revealed an $\sim 2$-fold increase in the proportion of SCs immunopositive for c-Jun in crushed roots of induced animals (Fig. 9G). Thus, caErbB2 SCs upregulate c-Jun in response to denervation, suggesting that they are converted to growth-promoting repair SCs via a c-Jun dependent mechanism. The increased number of c-Jun + SCs is also consistent with the prolonged SC dedifferentiation (Fig. 2) and enhanced axon regeneration (Fig. 4) observed in the crushed roots of caErbB2induced animals.

\section{Discussion}

\section{caErbB2 induction and denervated SCs}

The mechanisms that initiate SC dedifferentiation after injury remain unclear. Administration of neuregulin-1 and Mycobacterium leprae, which activate ErbB2 in SCs, induces rapid myelin breakdown and SC dedifferentiation (Trachtenberg and Thompson, 1997; Zanazzi et al., 2001; Tapinos et al., 2006). caErbB2 also induces innervated SCs of sciatic nerve to dedifferentiate, proliferate and extend processes (Hayworth et al., 2006). We observed that post-injury induction of caErbB2 similarly stimulates SCs in injured DRs to proliferate and form processes and delays their re-dedifferentiation. Our findings are consistent with the notion that NRG-1/ErbB signaling may initiate SC dedifferentiation after injury (C. Zhang et al., 2013; Lee et al., 2014).

It seems unlikely, however, that caErbB2 exerted the effects that we observed by initiating or facilitating SC dedifferentiation. ErbB2 is upregulated transiently after nerve injury (Carroll et al., 1997; Guertin et al., 2005; Fricker and Bennett, 2011; Ronchi et al., 2016) and activated within minutes (Guertin et al., 2005). Because induced expression of caErbB2 is unlikely to begin until days after feeding Dox to caErbB2 cTg mice (Hayworth et al., 2006), it is doubtful that caErbB2 participated in the initiation of SC dedifferentiation; more likely it acted by prolonging ErbB2 activation. This action would enhance proliferation and protract dedifferentiation, thus suppressing redifferentiation, of denervated SCs that had already dedifferentiated.

Genetic ablation of endogenous ErbB2 does not affect SC proliferation after injury (Atanasoski et al., 2006), but we found that increasing ErbB2 activation (i.e., by caErbB2) robustly enhances proliferation of denervated SCs. caErbB2 probably does so by activating downstream effectors such as Erk, Akt, and p38, all of which mediate SC proliferation (Maurel and Salzer, 2000; Monje et al., 2006; Mårtensson et al., 2007; Napoli et al., 2012).

\section{caErbB2 induction and innervated SCs}

Whereas caErbB2 markedly enhanced multiple responses of denervated SCs to DR injury, innervated SCs in uninjured DRs of the same animal remained remarkably quiescent. Several of our observations make it unlikely that this lack of SC reactivity was due to poor induction of caErbB2. First, S100 expression is substantially higher in innervated SCs than in denervated SCs (Son and Thompson, 1995a; Kang et al., 2007), which implies that S100 promoter in the transgene construct drives caErbB2 expression more powerfully in innervated than denervated SCs of caErbB2 cTg mice. Second, a previous study using a more sensitive GFP reporter line than ours showed rapid, strong induction of caErbB2 in innervated SCs of sciatic nerve in caErbB2 cTg mice (Hayworth et al., 2006). Third, our luciferase assay showed that caErbB2 induction was $\sim 5$-fold greater in injured roots than in uninjured roots, but injured roots contained $\sim 4$-fold more SCs. The lower luciferase activity (Fig. $1 B, C$ ) can therefore be attributed at least partly, if not entirely, to fewer SCs in intact DRs.
The differential reactivity likely indicates that the downstream effectors of caErbB2 mediate dedifferentiation and proliferation at different thresholds in innervated and denervated SCs, and that this threshold is higher in SCs with axon contacts. Our observation of minor sprouting of CGRP + , but not $\mathrm{NF}+$, axons in intact DRs also suggests that non-myelinating SCs have a lower threshold than myelinating SCs. Reports that Neuregulin/ErbB2 signaling is context dependent and regulated primarily by juxtacrine axon-SC interactions support this notion (Syed et al., 2010; Fricker and Bennett, 2011; Gambarotta et al., 2013). In addition, the vigorous responses of non-myelinating, terminal SCs (tSCs) to caErbB2 induction, including increased proliferation and migration, enhanced formation of $\mathrm{tSC}$ processes that induced and guided sprouting of intact axon terminals (Hayworth et al., 2006).

\section{caErbB2 induction and DR regeneration}

Although caErbB2 induction in SCs evoked minor sprouting of CGRP + axons in intact DRs, it strongly enhanced axon regeneration along the injured DRs. Earlier studies have consistently reported that administration of neuregulin isoforms improves peripheral nerve regeneration (Chang et al., 2013; Mancuso et al., 2016; Yasui et al., 2016). However, the two groups that bypassed ligand activation and directly targeted ErbB2 reported conflicting results: both genetic overexpression (Ronchi et al., 2013) and pharmacological inactivation of ErbB2 by Herceptin (Placheta et al., 2014; Hendry et al., 2016) improved nerve regeneration. These conflicting results may be in part due to non-SC associated activity of ErbB2 (Hendry et al., 2016). In contrast to these studies, we found that SC-selective ErbB2 activation robustly enhances axon regeneration.

Our findings also have an important implication for the mechanisms regulating SC plasticity after injury. Acute induction of caErbB2 post-injury enhanced proliferation and dedifferentiation of denervated SCs, markedly increasing the numbers of SCs and processes in the injured DR. The additional SCs and SC processes enabled more regenerating axons to form and grow along SC processes, strongly suggesting that caErbB2 SCs are growth-promoting repair SCs and that caErbB2 enhances regeneration by increasing their numbers. Providing further support for this notion are reports that caErbB2 SCs strongly express c-Jun (Fig. 9) and that ErbB2 signaling may regulate c-Jun (Yamauchi et al., 2008; Shin et al., 2013), a key transcription factor that converts dedifferentiated SCs to repair SCs (Arthur-Farraj et al., 2012). We cannot, however, exclude the possibility that caErbB2 increases the repair capacity of SCs at the level of the individual cell. Upregulated expression by the caErbB2 SC of NCAM, which promotes axon outgrowth on the SC surface (Bixby et al., 1988), is consistent with this idea. Our findings also demonstrate that, at least for the DR, acutely increasing SC proliferation after injury can be highly beneficial for augmenting axon regeneration.

\section{caErbB2 induction and axon regeneration across the DREZ}

The CNS-PNS boundary, or the DREZ, represents one of the most impenetrable barriers for regenerating axons (Han et al., 2012; Smith et al., 2012). Post-injury SC-selective caErbB2 induction evoked vigorous proliferation of SCs and axon regrowth along injured DRs, but neither SCs nor axons substantially penetrated the DREZ. We found that CSPGs did not arrest SC migration and axon regeneration at the DREZ, in contrast to earlier studies that had identified them as critical inhibitory factors. We found that intraspinally expressed GDNF enabled robust intraspinal migration of SCs, accompanied by axons, in caErbB2induced animals. Interestingly, GDNF did not drive migration of 
ordinary SCs across the DREZ in uninduced animals, indicating that its ability to stimulate SC migration or proliferation is insufficient to explain its caErbB2 SC-selective effects. One likely explanation is that caErbB2-expressing SCs react more vigorously to GDNF than ordinary SCs, consistent with their increased expression of NCAM, a coreceptor for GDNF. Their vigorous hyperactivity, including increased migration and proliferation, might also have enhanced the tropic effect of GDNF. Indeed, more caErbB2-expressing SCs penetrated the DREZ than ordinary denervated SCs, even without GDNF.

Previous efforts to promote re-entry of peripheral sensory axons into the adult spinal cord targeted either growth-inhibitory factors abundant in the CNS or the growth capacity of DRG neurons (Han et al., 2012; Smith et al., 2012). To our knowledge, neither of these strategies convincingly demonstrated that a majority of diverse DR axons re-entered the spinal cord. The present study is the first to promote DR regeneration by manipulating $\mathrm{SCs}$, and the first to show that combined expression of caErbB2 and GDNF produces robust penetration of most, if not all, axons into the spinal cord. Previous studies showed that combining GDNF with ordinary SCs improves axon regeneration after spinal cord injury (Deng et al., 2011, 2013). Our study suggests that GDNF can be a far more effective tool to promote CNS regeneration when applied in combination with SCs expressing caErbB2.

Neuregulin/ErbB signaling can be oncogenic and stimulate growth of benign Schwannomas and malignant SC tumors (Stonecypher et al., 2005; Hansen et al., 2006). Furthermore, uncontrolled, tumorigenic proliferation of denervated SCs accompanies severely impaired regeneration of sciatic nerves (Mindos et al., 2017). It was therefore very encouraging to observe that acute ErbB2 activation post-injury, which substantially increased proliferation of denervated SCs, markedly enhanced DR axon regeneration. Intriguingly, it did so without evoking overt changes in intact DRs. Our study therefore identifies ErbB2 as a potential therapeutic target and shows that the oncogenic Neuregulin/ ErbB signaling can be activated in a way that does not interfere with the conversion of denervated SCs to repair-competent SCs. We used heterozygous caErbB2 cTg mice for the present study because prolonged caErbB2 induction is lethal to the homozygous line (Hayworth et al., 2006). Moreover, we induced caErbB2 only for 2 weeks, which might also have helped to avoid tumorigenic ErbB2 activation. Consequently our results emphasize that a low level of caErbB2 expression, which evokes little change in intact nerves, greatly enhances axonal regeneration of damaged nerve. Spatiotemporal regulation of ErbB2 activation that avoids prolonged, excessive activation may be essential for its therapeutic application.

It will be very interesting to determine whether SC-selective delivery of caErbB2 will dramatically accelerate peripheral nerve regeneration and/or reactivate chronically denervated SCs, which could promote long-distance regeneration following proximal or chronic nerve injury. This strategy may also be further optimized to produce long-distance axon regeneration in the adult spinal cord.

\section{References}

Afshari FT, Kwok JC, White L, Fawcett JW (2010) Schwann cell migration is integrin-dependent and inhibited by astrocyte-produced aggrecan. Glia 58:857-869. CrossRef Medline

Arthur-Farraj PJ, Latouche M, Wilton DK, Quintes S, Chabrol E, Banerjee A, Woodhoo A, Jenkins B, Rahman M, Turmaine M, Wicher GK, Mitter R, Greensmith L, Behrens A, Raivich G, Mirsky R, Jessen KR (2012) c-Jun reprograms Schwann cells of injured nerves to generate a repair cell essential for regeneration. Neuron 75:633-647. CrossRef Medline
Atanasoski S, Scherer SS, Sirkowski E, Leone D, Garratt AN, Birchmeier C, Suter U (2006) ErbB2 signaling in Schwann cells is mostly dispensable for maintenance of myelinated peripheral nerves and proliferation of adult Schwann cells after injury. J Neurosci 26:2124-2131. CrossRef Medline

Ayuso E, Mingozzi F, Bosch F (2010) Production, purification and characterization of adeno-associated vectors. Curr Gene Ther 10:423-436. CrossRef Medline

Bargmann CI, Hung MC, Weinberg RA (1986) Multiple independent activations of the neu oncogene by a point mutation altering the transmembrane domain of p185. Cell 45:649-657. CrossRef Medline

Bixby JL, Lilien J, Reichardt LF (1988) Identification of the major proteins that promote neuronal process outgrowth on Schwann cells in vitro. J Cell Biol 107:353-361. CrossRef Medline

Bonilla IE, Tanabe K, Strittmatter SM (2002) Small proline-rich repeat protein $1 \mathrm{~A}$ is expressed by axotomized neurons and promotes axonal outgrowth. J Neurosci 22:1303-1315. Medline

Carroll SL, Miller ML, Frohnert PW, Kim SS, Corbett JA (1997) Expression of neuregulins and their putative receptors, ErbB2 and ErbB3, is induced during Wallerian degeneration. J Neurosci 17:1642-1659. Medline

Chan KM, Gordon T, Zochodne DW, Power HA (2014) Improving peripheral nerve regeneration: from molecular mechanisms to potential therapeutic targets. Exp Neurol 261:826-835. CrossRef Medline

Chang HM, Shyu MK, Tseng GF, Liu CH, Chang HS, Lan CT, Hsu WM, Liao WC (2013) Neuregulin facilitates nerve regeneration by speeding Schwann cell migration via ErbB2/3-dependent FAK pathway. PLoS One 8:e53444. CrossRef Medline

Chen YG, Brushart TM (1998) The effect of denervated muscle and Schwann cells on axon collateral sprouting. J Hand Surg Am 23:1025-1033. CrossRef Medline

Chong MS, Reynolds ML, Irwin N, Coggeshall RE, Emson PC, Benowitz LI, Woolf CJ (1994) GAP-43 expression in primary sensory neurons following central axotomy. J Neurosci 14:4375-4384. Medline

Curinga GM, Snow DM, Mashburn C, Kohler K, Thobaben R, Caggiano AO, Smith GM (2007) Mammalian-produced chondroitinase AC mitigates axon inhibition by chondroitin sulfate proteoglycans. J Neurochem 102: 275-288. CrossRef Medline

Deng LX, Hu J, Liu N, Wang X, Smith GM, Wen X, Xu XM (2011) GDNF modifies reactive astrogliosis allowing robust axonal regeneration through Schwann cell-seeded guidance channels after spinal cord injury. Exp Neurol 229:238-250. CrossRef Medline

Deng LX, Deng P, Ruan Y, Xu ZC, Liu NK, Wen X, Smith GM, Xu XM (2013) A novel growth-promoting pathway formed by GDNF-overexpressing Schwann cells promotes propriospinal axonal regeneration, synapse formation, and partial recovery of function after spinal cord injury. J Neurosci 33:5655-5667. CrossRef Medline

DePaul MA, Lin CY, Silver J, Lee YS (2015) Peripheral nerve transplantation combined with acidic fibroblast growth factor and chondroitinase induces regeneration and improves urinary function in complete spinal cord transected adult mice. PLoS One 10:e0139335. CrossRef Medline

Di Maio A, Skuba A, Himes BT, Bhagat SL, Hyun JK, Tessler A, Bishop D, Son YJ (2011) In vivo imaging of dorsal root regeneration: rapid immobilization and presynaptic differentiation at the CNS/PNS border. J Neurosci 31:4569-4582. CrossRef Medline

Feng G, Mellor RH, Bernstein M, Keller-Peck C, Nguyen QT, Wallace M, Nerbonne JM, Lichtman JW, Sanes JR (2000) Imaging neuronal subsets in transgenic mice expressing multiple spectral variants of GFP. Neuron 28:41-51. CrossRef Medline

Fontana X, Hristova M, Da Costa C, Patodia S, Thei L, Makwana M, SpencerDene B, Latouche M, Mirsky R, Jessen KR, Klein R, Raivich G, Behrens A (2012) c-Jun in Schwann cells promotes axonal regeneration and motoneuron survival via paracrine signaling. J Cell Biol 198:127-141. CrossRef Medline

Fouad K, Schnell L, Bunge MB, Schwab ME, Liebscher T, Pearse DD (2005) Combining Schwann cell bridges and olfactory-ensheathing glia grafts with chondroitinase promotes locomotor recovery after complete transection of the spinal cord. J Neurosci 25:1169-1178. CrossRef Medline

Fricker FR, Bennett DL (2011) The role of neuregulin-1 in the response to nerve injury. Future Neurol 6:809-822. CrossRef Medline

Fu SY, Gordon T (1995) Contributing factors to poor functional recovery after delayed nerve repair: prolonged denervation. J Neurosci 15:38863895. Medline

Gai WP, Zhou XF, Rush RA (1996) Analysis of low affinity neurotrophin 
receptor ( $\mathrm{p} 75)$ expression in glia of the CNS-PNS transition zone following dorsal root transection. Neuropathol Appl Neurobiol 22:434-439. CrossRef Medline

Gambarotta G, Fregnan F, Gnavi S, Perroteau I (2013) Neuregulin 1 role in Schwann cell regulation and potential applications to promote peripheral nerve regeneration. Int Rev Neurobiol 108:223-256. CrossRef Medline

Gomez-Sanchez JA, Pilch KS, van der Lans M, Fazal SV, Benito C, Wagstaff LJ, Mirsky R, Jessen KR (2017) After nerve injury, lineage tracing shows that myelin and remak Schwann cells elongate extensively and branch to form repair Schwann cells, which shorten radically on remyelination. J Neurosci 37:9086-9099. CrossRef Medline

Gordon T (2016) Nerve regeneration: understanding biology and its influence on return of function after nerve transfers. Hand Clin 32:103-117. CrossRef Medline

Gordon T, English AW (2016) Strategies to promote peripheral nerve regeneration: electrical stimulation and/or exercise. Eur J Neurosci 43:336350. CrossRef Medline

Gordon T, Tyreman N, Raji MA (2011) The basis for diminished functional recovery after delayed peripheral nerve repair. J Neurosci 31:5325-5334. CrossRef Medline

Grimpe B, Pressman Y, Lupa MD, Horn KP, Bunge MB, Silver J (2005) The role of proteoglycans in Schwann cell/astrocyte interactions and in regeneration failure at PNS/CNS interfaces. Mol Cell Neurosci 28:18-29. CrossRef Medline

Guertin AD, Zhang DP, Mak KS, Alberta JA, Kim HA (2005) Microanatomy of axon/glial signaling during Wallerian degeneration. J Neurosci 25: 3478-3487. CrossRef Medline

Han SB, Kim H, Skuba A, Tessler A, Ferguson T, Son YJ (2012) Sensory axon regeneration: a review from an in vivo imaging perspective. Exp Neurobiol 21:83-93. CrossRef Medline

Hansen MR, Roehm PC, Chatterjee P, Green SH (2006) Constitutive neuregulin-1/ErbB signaling contributes to human vestibular schwannoma proliferation. Glia 53:593-600. CrossRef Medline

Harrisingh MC, Perez-Nadales E, Parkinson DB, Malcolm DS, Mudge AW, Lloyd AC (2004) The Ras/Raf/ERK signalling pathway drives Schwann cell dedifferentiation. EMBO J 23:3061-3071. CrossRef Medline

Havton LA, Carlstedt T (2009) Repair and rehabilitation of plexus and root avulsions in animal models and patients. Curr Opin Neurol 22:570-574. CrossRef Medline

Hayworth CR, Moody SE, Chodosh LA, Krieg P, Rimer M, Thompson WJ (2006) Induction of neuregulin signaling in mouse schwann cells in vivo mimics responses to denervation. J Neurosci 26:6873-6884. CrossRef Medline

Hendry JM, Alvarez-Veronesi MC, Placheta E, Zhang JJ, Gordon T, Borschel GH (2016) ErbB2 blockade with Herceptin (trastuzumab) enhances peripheral nerve regeneration after repair of acute or chronic peripheral nerve injury. Ann Neurol 80:112-126. CrossRef Medline

Höke A (2006) Mechanisms of disease: what factors limit the success of peripheral nerve regeneration in humans? Nat Clin Pract Neurol 2:448454. CrossRef Medline

Höke A, Ho T, Crawford TO, LeBel C, Hilt D, Griffin JW (2003) Glial cell line-derived neurotrophic factor alters axon Schwann cell units and promotes myelination in unmyelinated nerve fibers. J Neurosci 23:561-567. Medline

Iwase T, Jung CG, Bae H, Zhang M, Soliven B (2005) Glial cell line-derived neurotrophic factor-induced signaling in Schwann cells. J Neurochem 94:1488-1499. CrossRef Medline

Jessen KR, Mirsky R (2016) The repair Schwann cell and its function in regenerating nerves. J Physiol 594:3521-3531. CrossRef Medline

Jin Y, Ketschek A, Jiang Z, Smith G, Fischer I (2011) Chondroitinase activity can be transduced by a lentiviral vector in vitro and in vivo. J Neurosci Methods 199:208-213. CrossRef Medline

Kang H, Lichtman JW (2013) Motor axon regeneration and muscle reinnervation in young adult and aged animals. J Neurosci 33:1948019491. CrossRef Medline

Kang H, Tian L, Son YJ, Zuo Y, Procaccino D, Love F, Hayworth C, Trachtenberg J, Mikesh M, Sutton L, Ponomareva O, Mignone J, Enikolopov G, Rimer M, Thompson W (2007) Regulation of the intermediate filament protein nestin at rodent neuromuscular junctions by innervation and activity. J Neurosci 27:5948-5957. CrossRef Medline

Kelamangalath L, Tang X, Bezik K, Sterling N, Son YJ, Smith GM (2015)
Neurotrophin selectivity in organizing topographic regeneration of nociceptive afferents. Exp Neurol 271:262-278. CrossRef Medline

Kidd GJ, Ohno N, Trapp BD (2013) Biology of Schwann cells. Handb Clin Neurol 115:55-79. CrossRef Medline

Kuffler DP (2014) An assessment of current techniques for inducing axon regeneration and neurological recovery following peripheral nerve trauma. Prog Neurobiol 116:1-12. CrossRef Medline

Lee HJ, Shin YK, Park HT (2014) Mitogen activated protein kinase family proteins and c-jun signaling in injury-induced Schwann cell plasticity. Exp Neurobiol 23:130-137. CrossRef Medline

Lin CL, Heron P, Hamann SR, Smith GM (2014) Functional distinction between NGF-mediated plasticity and regeneration of nociceptive axons within the spinal cord. Neuroscience 272:76-87. CrossRef Medline

Lino MM, Atanasoski S, Kvajo M, Fayard B, Moreno E, Brenner HR, Suter U, Monard D (2007) Mice lacking protease nexin-1 show delayed structural and functional recovery after sciatic nerve crush. J Neurosci 27: 3677-3685. CrossRef Medline

Liu Y, Kelamangalath L, Kim H, Han SB, Tang X, Zhai J, Hong JW, Lin S, Son YJ, Smith GM (2016) NT-3 promotes proprioceptive axon regeneration when combined with activation of the mTor intrinsic growth pathway but not with reduction of myelin extrinsic inhibitors. Exp Neurol 283:73-84. CrossRef Medline

Mancuso R, Martínez-Muriana A, Leiva T, Gregorio D, Ariza L, Morell M, Esteban-Pérez J, García-Redondo A, Calvo AC, Atencia-Cibreiro G, Corfas G, Osta R, Bosch A, Navarro X (2016) Neuregulin-1 promotes functional improvement by enhancing collateral sprouting in SOD1(G93A) ALS mice and after partial muscle denervation. Neurobiol Dis 95:168178. CrossRef Medline

Mårtensson L, Gustavsson P, Dahlin LB, Kanje M (2007) Activation of extracellular-signal-regulated kinase-1/2 precedes and is required for injury-induced Schwann cell proliferation. Neuroreport 18:957-961. CrossRef Medline

Matsumoto M, Hirata H, Nishiyama M, Morita A, Sasaki H, Uchida A (1999) Schwann cells can induce collateral sprouting from intact axons: experimental study of end-to-side neurorrhaphy using a Y-chamber model. J Reconstr Microsurg 15:281-286. CrossRef Medline

Maurel P, Salzer JL (2000) Axonal regulation of Schwann cell proliferation and survival and the initial events of myelination requires PI 3-kinase activity. J Neurosci 20:4635-4645. Medline

Mindos T, Dun XP, North K, Doddrell RD, Schulz A, Edwards P, Russell J, Gray B, Roberts SL, Shivane A, Mortimer G, Pirie M, Zhang N, Pan D, Morrison H, Parkinson DB (2017) Merlin controls the repair capacity of Schwann cells after injury by regulating Hippo/YAP activity. J Cell Biol 216:495-510. CrossRef Medline

Monje PV, Bartlett Bunge M, Wood PM (2006) Cyclic AMP synergistically enhances neuregulin-dependent ERK and Akt activation and cell cycle progression in Schwann cells. Glia 53:649-659. CrossRef Medline

Moody SE, Sarkisian CJ, Hahn KT, Gunther EJ, Pickup S, Dugan KD, Innocent N, Cardiff RD, Schnall MD, Chodosh LA (2002) Conditional activation of Neu in the mammary epithelium of transgenic mice results in reversible pulmonary metastasis. Cancer Cell 2:451-461. CrossRef Medline

Nakamura SI, Myers RR (2000) Injury to dorsal root ganglia alters innervation of spinal cord dorsal horn lamina involved in nociception. Spine 25:537-542. CrossRef Medline

Napoli I, Noon LA, Ribeiro S, Kerai AP, Parrinello S, Rosenberg LH, Collins MJ, Harrisingh MC, White IJ, Woodhoo A, Lloyd AC (2012) A central role for the ERK-signaling pathway in controlling Schwann cell plasticity and peripheral nerve regeneration in vivo. Neuron 73:729-742. CrossRef Medline

Naveilhan P, ElShamy WM, Ernfors P (1997) Differential regulation of mRNAs for GDNF and its receptors Ret and GDNFR alpha after sciatic nerve lesion in the mouse. Eur J Neurosci 9:1450-1460. CrossRef Medline

Oblinger MM, Lasek RJ (1984) A conditioning lesion of the peripheral axons of dorsal root ganglion cells accelerates regeneration of only their peripheral axons. J Neurosci 4:1736-1744. Medline

Painter MW, Brosius Lutz A, Cheng YC, Latremoliere A, Duong K, Miller CM, Posada S, Cobos EJ, Zhang AX, Wagers AJ, Havton LA, Barres B, Omura T, Woolf CJ (2014) Diminished Schwann cell repair responses underlie age-associated impaired axonal regeneration. Neuron 83:331343. CrossRef Medline

Palispis WA, Gupta R (2017) Surgical repair in humans after traumatic 
nerve injury provides limited functional neural regeneration in adults. Exp Neurol 290:106-114. CrossRef Medline

Paratcha G, Ledda F, Ibáñez CF (2003) The neural cell adhesion molecule NCAM is an alternative signaling receptor for GDNF family ligands. Cell 113:867-879. CrossRef Medline

Parkinson DB, Bhaskaran A, Arthur-Farraj P, Noon LA, Woodhoo A, Lloyd AC, Feltri ML, Wrabetz L, Behrens A, Mirsky R, Jessen KR (2008) c-Jun is a negative regulator of myelination. J Cell Biol 181:625-637. CrossRef Medline

Placheta E, Hendry JM, Wood MD, Lafontaine CW, Liu EH, Cecilia Alvarez Veronesi M, Frey M, Gordon T, Borschel GH (2014) The ErbB2 inhibitor Herceptin (Trastuzumab) promotes axonal outgrowth four weeks after acute nerve transection and repair. Neurosci Lett 582:81-86. CrossRef Medline

Ramer MS, McMahon SB, Priestley JV (2001) Axon regeneration across the dorsal root entry zone. Prog Brain Res 132:621-639. CrossRef Medline

Ronchi G, Gambarotta G, Di Scipio F, Salamone P, Sprio AE, Cavallo F, Perroteau I, Berta GN, Geuna S (2013) ErbB2 receptor over-expression improves post-traumatic peripheral nerve regeneration in adult mice. PLoS One 8:e56282. CrossRef Medline

Ronchi G, Haastert-Talini K, Fornasari BE, Perroteau I, Geuna S, Gambarotta G (2016) The Neuregulin1/ErbB system is selectively regulated during peripheral nerve degeneration and regeneration. Eur J Neurosci 43:351364. CrossRef Medline

Scheib J, Höke A (2013) Advances in peripheral nerve regeneration. Nat Rev Neurol 9:668-676. CrossRef Medline

Scholz T, Krichevsky A, Sumarto A, Jaffurs D, Wirth GA, Paydar K, Evans GR (2009) Peripheral nerve injuries: an international survey of current treatments and future perspectives. J Reconstr Microsurg 25:339-344. CrossRef Medline

Sheu JY, Kulhanek DJ, Eckenstein FP (2000) Differential patterns of ERK and STAT3 phosphorylation after sciatic nerve transection in the rat. Exp Neurol 166:392-402. CrossRef Medline

Shin YK, Jang SY, Park JY, Park SY, Lee HJ, Suh DJ, Park HT (2013) The Neuregulin-Rac-MKK7 pathway regulates antagonistic c-jun/Krox20 expression in Schwann cell dedifferentiation. Glia 61:892-904. CrossRef Medline

Smith GM, Falone AE, Frank E (2012) Sensory axon regeneration: rebuilding functional connections in the spinal cord. Trends Neurosci 35:156163. CrossRef Medline

Son YJ, Thompson WJ (1995a) Schwann cell processes guide regeneration of peripheral axons. Neuron 14:125-132. CrossRef Medline

Son YJ, Thompson WJ (1995b) Nerve sprouting in muscle is induced and guided by processes extended by Schwann cells. Neuron 14:133-141. CrossRef Medline

Starkey ML, Davies M, Yip PK, Carter LM, Wong DJ, McMahon SB, Bradbury EJ (2009) Expression of the regeneration-associated protein SPRR1A in primary sensory neurons and spinal cord of the adult mouse following peripheral and central injury. J Comp Neurol 513:51-68. CrossRef Medline

Steinmetz MP, Horn KP, Tom VJ, Miller JH, Busch SA, Nair D, Silver DJ, Silver J (2005) Chronic enhancement of the intrinsic growth capacity of sensory neurons combined with the degradation of inhibitory proteoglycans allows functional regeneration of sensory axons through the dorsal root entry zone in the mammalian spinal cord. J Neurosci 25:8066-8076. CrossRef Medline

Stonecypher MS, Byer SJ, Grizzle WE, Carroll SL (2005) Activation of the neuregulin-1/ErbB signaling pathway promotes the proliferation of neoplastic Schwann cells in human malignant peripheral nerve sheath tumors. Oncogene 24:5589-5605. CrossRef Medline
Sulaiman OA, Gordon T (2000) Effects of short- and long-term Schwann cell denervation on peripheral nerve regeneration, myelination, and size. Glia 32:234-246. CrossRef Medline

Sulaiman OA, Gordon T (2009) Role of chronic Schwann cell denervation in poor functional recovery after nerve injuries and experimental strategies to combat it. Neurosurgery 65:A105-114. CrossRef Medline

Syed N, Reddy K, Yang DP, Taveggia C, Salzer JL, Maurel P, Kim HA (2010) Soluble neuregulin-1 has bifunctional, concentration-dependent effects on Schwann cell myelination. J Neurosci 30:6122-6131. CrossRef Medline

Tapinos N, Ohnishi M, Rambukkana A (2006) ErbB2 receptor tyrosine kinase signaling mediates early demyelination induced by leprosy bacilli. Nat Med 12:961-966. CrossRef Medline

Trachtenberg JT, Thompson WJ (1997) Nerve terminal withdrawal from rat neuromuscular junctions induced by neuregulin and Schwann cells. J Neurosci 17:6243-6255. Medline

Triolo D, Dina G, Lorenzetti I, Malaguti M, Morana P, Del Carro U, Comi G, Messing A, Quattrini A, Previtali SC (2006) Loss of glial fibrillary acidic protein (GFAP) impairs Schwann cell proliferation and delays nerve regeneration after damage. J Cell Sci 119:3981-3993. CrossRef Medline

Trupp M, Belluardo N, Funakoshi H, Ibáñez CF (1997) Complementary and overlapping expression of glial cell line-derived neurotrophic factor (GDNF), c-ret proto-oncogene, and GDNF receptor-alpha indicates multiple mechanisms of trophic actions in the adult rat CNS. J Neurosci 17:3554-3567. Medline

Wu D, Klaw MC, Kholodilov N, Burke RE, Detloff MR, Côté MP, Tom VJ (2016) Expressing constitutively active rheb in adult dorsal root ganglion neurons enhances the integration of sensory axons that regenerate across a chondroitinase-treated dorsal root entry zone following dorsal root crush. Front Mol Neurosci 9:49. CrossRef Medline

Wujek JR, Lasek RJ (1983) Correlation of axonal regeneration and slow component B in two branches of a single axon. J Neurosci 3:243-251. Medline

Yamauchi J, Miyamoto Y, Chan JR, Tanoue A (2008) ErbB2 directly activates the exchange factor Dock7 to promote Schwann cell migration. J Cell Biol 181:351-365. CrossRef Medline

Yang DP, Kim J, Syed N, Tung YJ, Bhaskaran A, Mindos T, Mirsky R, Jessen KR, Maurel P, Parkinson DB, Kim HA (2012) p38 MAPK activation promotes denervated Schwann cell phenotype and functions as a negative regulator of Schwann cell differentiation and myelination. J Neurosci 32:7158-7168. CrossRef Medline

Yasui G, Yamamoto Y, Shichinohe R, Funayama E, Oyama A, Hayashi T, Furukawa H (2016) Neuregulin-1 released by biodegradable gelatin hydrogels can accelerate facial nerve regeneration and functional recovery of traumatic facial nerve palsy. J Plast Reconstr Aesthet Surg 69:328-334. CrossRef Medline

Zanazzi G, Einheber S, Westreich R, Hannocks MJ, Bedell-Hogan D, Marchionni MA, Salzer JL (2001) Glial growth factor/neuregulin inhibits Schwann cell myelination and induces demyelination. J Cell Biol 152: 1289-1299. CrossRef Medline

Zhang C, Jin Y, Ziemba KS, Fletcher AM, Ghosh B, Truit E, Yurek DM, Smith GM (2013) Long distance directional growth of dopaminergic axons along pathways of netrin-1 and GDNF. Exp Neurol 250:156-164. CrossRef Medline

Zhang L, Ma Z, Smith GM, Wen X, Pressman Y, Wood PM, Xu XM (2009) GDNF-enhanced axonal regeneration and myelination following spinal cord injury is mediated by primary effects on neurons. Glia 57:11781191. CrossRef Medline

Zochodne DW (2012) The challenges and beauty of peripheral nerve regrowth. J Peripher Nerv Syst 17:1-18. CrossRef Medline 